http://kitaibelia.unideb.hu/

ISSN 2064-4507 (Online) • ISSN 1219-9672 (Print)

(C) Department of Botany, University of Debrecen, Hungary

23 (2): 218-237.; 2018

DOI: $10.17542 /$ kit.23.218

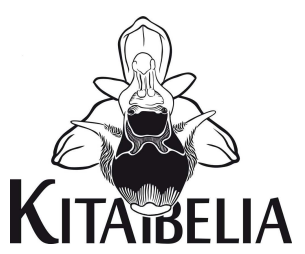

\title{
Pótlások Magyarország edényes növényfajainak elterjedési atlaszához VII.
}

\author{
Kevey Balázs \\ Pécsi Tudományegyetem, Ökológiai Tanszék, H-7624 Pécs Ifjúság útja 6.; keveyb@gamma.ttk.pte.hu
}

\section{Contributions to the Atlas Florae Hungariae VII.}

\begin{abstract}
This paper lists supplementary data to the recently published Atlas Florae Hungariae, mostly from various parts of Transdanubia and the Great Plain. The list includes 73 plant species with at least one new occurrence previously not shown on their grid-based range map, as well as data confirming old records or correcting erroneous distribution data. The actual habitats where the plants occur are characterized by their corresponding ÁNÉR codes.
\end{abstract}

Keywords: ÁNÉR, chorology, floristic surveys, Hungary, vascular flora

Összefoglalás - Jelen dolgozat a nemrég megjelent magyarországi flóraatlaszhoz tartalmaz kiegészítő adatokat, elsősorban a Dunántúl és az Alföld területéről. A közölt adatok a fajok elterjedési térképén új előfordulási pontokat jelentenek, vagy megerősítenek régi adatokat, további esetekben korábban publikált adatokat helyesbítenek. A közlemény 73 növényfajról tartalmaz florisztikai adatokat, illetve élőhelyeik ÁNÉR kódjait.

Kulcsszavak: cönológia, elterjedés, florisztika, hajtásos növények, Magyarország

\section{Bevezetés}

A magyarországi flóraatlasz (BARTHA et al. 2015) elterjedési térképeinek kiegészítését célzó cikksorozatban (TAKÁCS et al. 2016., MolnÁR et al. 2016, 2017, 2018, CSIKY et al. 2017) nemrég jelent meg egy cikkem (KEVEY 2017a). Azóta tovább böngésztem a cönológiai felvételeimet, egyéb jegyzeteimet és korábbi publikációimat, és ismét hasonló mennyiségű olyan adatra bukkantam, amelyek a flóratérképekre nézve újak.

Az alábbi adatsorban a fajok előfordulási adatait a következő struktúrában közlöm: földrajzi táj (rövidítéseik jegyzéke a közlemény végén található), a közép-európai flóra-térképezés raszterkódja (NIKLFELD 1971 szerint), településhatár, dülőnév, az élőhely ÁNÉR-kódja (BöLÖNI et al. 2011 szerint), az első felfedezés évszáma, illetve a korábban már publi-kált lelőhely esetében a forrás megjelölése. Az adatok területi eloszlását az 1. ábra szemlél-teti. Ezek túlnyomó része a Szigetköz, a Dunántúli-középhegység, és a Dél-Dunántúl területét érinti, de bőven vannak adatok a Hanság, a Rába és a Marcal vidékéről, a Csepel-szigetről, a Mezőföldről, valamint a hazai Alsó-Duna-ártér, a Duna-Tisza köze, és az Alföld északkeleti részéről (Bodrogköz, Bereg-Szatmári-sík, Nyírség). A fajok alfabetikus sorrendben követik egymást a harasztok, kétszikűek és egyszikűek külön rendezve. A fajok nómenklatúrája KIRÁLY (2009) munkáját követi. 


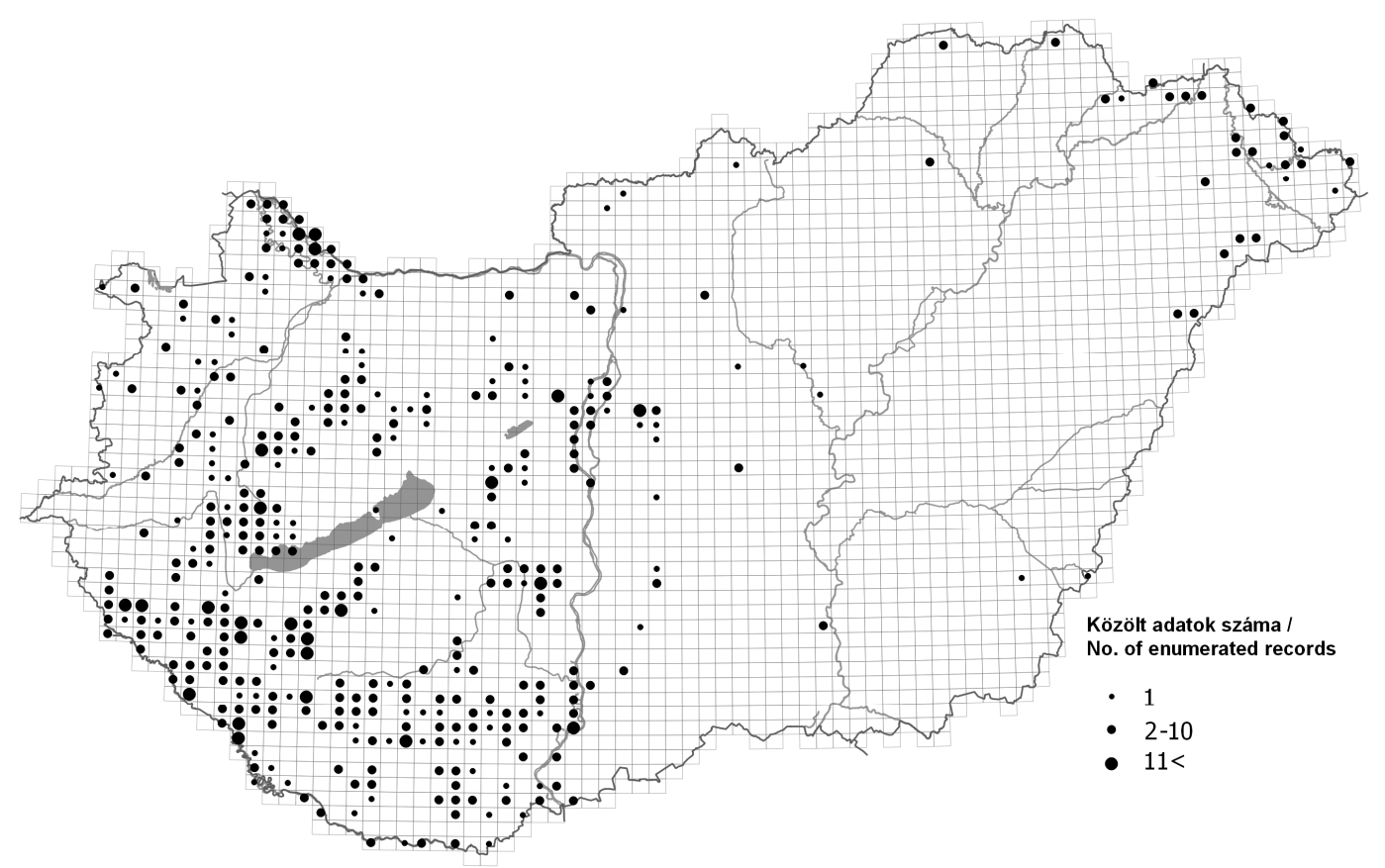

1. ábra. A közleményben összefoglalt előfordulási adatok a közép-európai flóratérképezés (KEF) hálórendszerének kvadrátjaira vetítve

Fig. 1. Distribution of localities of the presented data, projected on the quadrates of the Central European flora mapping system (CEU)

\section{Adatok felsorolása}

Pteridophyta

Asplenium adiantum-nigrum L. - Mcs: 9776/4: Zengővárkony „Réka-völgy” K7a (K: 2003).

Dryopteris affinis (Löve) Fraser-Jenk. - ÉZ: 9168/3: Nagykapornak „Zombori” J5 (KeVEY 2015a: 40).

Dryopteris carthusiana (Vill.) H.P. Fuchs - H: 8169/4: Újrónaf” „Krisztina-berek” J6 (K: 2001). 8367/3: Fertőd „Eszterházi-Lés-erdő” J6 (K: 1985). R: 8369/2: Maglóca „Sziget-erdő” J6 (K: 1996). VRv: 8767/2: Sárvár „Sitkei-erdő” K1a (Kevey 2015e: 224). Mm: 8768/4: Izsákfa „Lap-Cenki-erdő” K1a (K: 2012). 8869/4: Tüskevár „Tüskevári-erdő” J6, K1a (K: 2011). 8870/1: Doba „Felső-erdő” J6, K1a (K: 2012). 8869/4: Apácatorna „Galsai-erdő” J6, K1a (K: 2013). Mf: 9075/3: Enying „Kustyánerdő” J2, J5. (K: 2011). 9176/1: Dég „Kastély-park: egyetlen tő a Kislángi-árok mellett” J6 (KEVEY 1984: 52). 9278/3: Bikács-Kistápé „Dombi-rét” L5 (KeVEY \& LendVAi in KeVeY 2015c: 17). 9278/4: Németkér „Barát-erdő” K1a (Kevey et TótH I. Zs. 2016: 19). SDs: 9868/2: Somogyudvarhely „Vecsenye” J6, K1a (Kevey 2007c: 107). 9869/3: Bélavár „Bereki-erdő” J6, K1a (Kevey 2007c: 107). BDs: 0274/2: Tésenfa „Támasó” J4 (KeveY \& Tóth V. 2006: 54). HNs: 0077/3: Borjád „Borjádi-erdő” K1a (Kevey 2008: 38/1. táblázat). Tv: 8781/2: Ócsa „Ómér-erdő” J5, J6 (K: 2016). DTk: 9381/2: Tabdi „Tabdi-erdő” J2 (K: 2004). Bk: 7695/4: Sátoraljaújhely „Long-erdő” J6, K1a (K: 2007). 7696/3: Sátoraljaújhely „Long-erdő” J6, K1a (K: 2007). 7697/1: Pácin „Mosonnai-erdő” J6, K1a (K: 2008). 7698/3: Révleányvár „Pap-erdő” J6, K1a (K: 2008), „Bodzás” J6, K1a (K: 2008). 7698/4: Zemplénagárd „Tiszaártér” J6, K1a (K: 2008). BSzs: 7901/2: Kömörő „Páskom” J6, K1a (K: 2003). 7903/1: Magosliget „Cserköz-erdő” K1a (K: 2009). Ny: 7998/4: Baktalórántháza „Baktai-erdő” K1a (KeveY in KeveY et al. 2017a: E1. táblázat). 8100/3: Tiborszállás „Ezüsttábla” K1a (KeVEY in KeveY et al. 2017a: E1. táblázat). Mérk „Vadaskerti-erdő” J6, K1a (KeVEY, LENDVAI et PAPP L. ined.: 2007). 8497/2: Nyíracsád „Jónás-rész” J2 (Kevey et Papp L.: 2004). 8498/1: Nyírábrány „Kiskőrises” J2 (KevEY et al. 2017b: 190). Khg: 9069/3: Zalaszántó „Kovácsi-hegy” J5 (K: 2000). 9169/1: Rezi „Hosszú-völgy” LY1 
(K: 1984). 9169/2: Zalaszántó „Vár-berek” J6, K1a (K: 2006). Ba: 8672/2: Fenyőfő „Kuruc-erdő” K1a (Kevey 2014: 58). 8871/3: Devecser „Beréndi-erdo” J6, K1a (K: 2005). B: 8672/3: Ugod „Gerencevölgy” J5 (K: 1996). 8773/4: Olaszfalu-Alsópere „Puszta-berek” J5 (K: 1996). 8774/2: Isztimér „Burok-völgy” LY1 (K: 2013). 9069/2: Sümeg „Fehér-kövek” K5 (K: 2005). Bö: 8080/1: Borsosberény „Láz-lapos” J5 (K: 1996). Tk: 7490/4: Bódvarákó „Esztrámos és Kis-hegy között” J5 (K: 1994). ÉZ: 9168/3: Almásháza „Páskom” K2 (K: 1993). 9268/1: Rádó „Büki-erdő” K2, K5 (K: 1992). DZ: Újudvar "Csibiti-völgy” LY1 (KeVEY 2008: 44/1. táblázat). 9566/2: Valkonya „a Valkonyai-patak melletti erdőben” K5 (K: 2008). 9567/2: Hosszúvölgy „Zsigárdi-erdő” J6, K1a (K: 2015). BS: 9369/2: Balatonszentgyörgy „Battyánpusztai-erdő” J6 (K: 2017). 9469/3: Zalakomár-Ormándpuszta „Csöngőkút” J5, J6 (K: 1989). Szőkedencs „Csörgető” J6 (K: 1998). 9469/4: Csákány „Hertelendi-erdő” J6, K1a (K: 1998). Somogyzsitfa-Szőcsénypuszta „Margitsétány” J6 (K: 1996). 9471/1: Csömend „Koszód” J6 (K: 1990). 9471/3: Libickozma „Kopári-erdő” K1a (K: 2007). 9569/1: Somogysimonyi „Gödörberkierdő” J5, J6 (K: 1998). 9571/3: Nagybajom „Középső-Kak” J5, K1a (KeveY 2013a: 24), „Felső-Csikotaierdő” J5, K1a, K5 (KEVEY 2013a: 24), „Lencsenpuszta és Szili-bükk között” K1a, K5 (KEVEY 2013a: 24). 9771/1: Nagykorpád „Mórici-erdő” J5, K1a (K: 2017). KS: 9372/4: Gamás-Vadépuszta „Vadéi-erdő” J5 (K: 1977). 9472/1: Somogyvár „Télizöld” J5 (K: 1998). Zs: 9672/3: BárdudvarnokKaposszentbenedek „Barát-völgy” J5 (K: 1985). 9673/3: Sántos „Öreg-hegy” LY1 (Kevey 2010: 34; KEVEY 2013c: 35). 9772/1: Szenna „Dennai-erdő” J5, K1a (K: 2009). 9772/2: Bőszénfa „Ropoly” J6, K1a (K: 2004). 9772/3: Visnye „Boros-erdő” J6, K1a (K: 2016). 9772/4: Bőszénfa-Kardosfapuszta „Tergócs-erdő” K2 (K: 2017). 9773/1: Kaposgyarmat „Tótfalusi-erdő” J5, J6, K1a (K: 2017). 9773/3: Bőszénfa „Farkaslak” K2, K5 (K: 1976). Vlhg: 0075/4: Bisse „Poszhagymás” K1a (K: 1980). Gd: 9877/3: Geresdlak „Kisgeresdi-erdő” K1a (K: 2004).

Dryopteris cristata (L.) A. Gray - BS: 9469/3: Zalakomár-Ormándpuszta „Csöngő-kút” J2 (KevEY 1993: 54). Az 1990-ben talált héttagú kis populáció azóta egyre zsugorodott, míg 1996-ban már egyetlen példány sem hajtott ki (vö. KEvEY 2001: 96). A lelőhely így kihaltnak tekintendő.

Dryopteris dilatata (Hoffm.) A. Gray - Sk: 9879/1: Báta „Gyürűsalj” K1a (Kevey \& TóTH I. 2000: 133). Mm: 8768/4: Izsákfa „Lap-Cenki-erdő” K1a (K: 2012). Tv: 8781/2: Ócsa „Ómér-erdő” J5, J6 (K: 2016). BSzs: 7700/1: Tiszakerecseny „Lónyai-erdő" J6 (K: 2010). BDs: 0172/2: Sellye „Bogdásai-erdő” J6, K1a (K: 1997). SDs: 9869/1: Somogyudvarhely „Vecsenye” J6, K1a (Kevey 2013b: 106). VRv: 8767/2: Sárvár „Sitkei-erdő” K1a (K: 2014). Vh: 8967/1: Kám „Jeli: Hét-forrás K5 (K: 1998). Ba: 8672/1: Pápateszér „Görgő-ér” J5, K1a (Kevey 2015b: 60), „Mehetősi-erdő” K1a (KeVEY 2015b: 60). 8672/2: Fenyőfo „Halastói-patak” K1a (Kevey 2015b: 60). 8770/4: Kúp „Kúpi-erdő” J5, J6, K1a (K: 1989). Khg: 9069/3: Zalaszántó „Kovácsi-hegy” J5 (K: 2000). 9069/4: Lesenceistvánd-Uzsa „Hubertusz” K1a (K: 2000). Bazsi „Bazsi-erdő” K1a (K: 2007). 9169/2: Zalaszántó „Láz-berek” J5, K1a (K: 2000), „Várberek” J5, J6, K1a (K: 2006). B: 8673/3: Csesznek „Zsellér-erdő” K5 (K: 1994). 8772/1: Ugod „Nagyförtési-árok” LY1 (K: 1998). 8773/4: Olaszfalu-Alsópere „Puszta-berek” J5 (K: 2012). 8774/2: Isztimér „Burok-völgy” LY1 (K: 1996). Kv: 9365/3: Lenti „Alsó-erdő” J6, K1a (K: 2011). 9465/2: Iklódbördöce „Cserta-torkolat” J6, K1a (K: 2011). 9566/1: Letenye „Kecske-hát” J6, K1a (K: 2005), „Csitári-erdő” J6, K1a (K: 2005). ÉZ: 9068/3: Csáford „Dabrony” K2 (K: 1993). 9168/1: Kallosd „Kaponya” J5, K1a (K: 1991). Gyürüs „Kígyós” K1a (K: 1993). 9168/3: Nagykapornak „Vecei-erdő” K2, K5 (K: 1992), „Tilaji-erdő” J5 (K: 1992). Almásháza „Páskom” K2, K5 (K: 1993). 9267/2: Rádó „Kőhegy” K2 (K: 1993). 9267/3: Pölöske „Sohollár” J5, K2 (K: 2014). 9267/4: Zalaszentmihály „Sinkeierdő” J5, J6 (K: 2012). 9268/1: Rádó „Büki-erdő” K2, K5 (K: 1992). DZ: 9465/2: Tormafölde „Vétyemi-erdő: Angyalirta-árok” LY1 (Kevey 2008: 44/1. táblázat), „Csokmai-erdő” K2, K5 (K: 2012). 9466/1: Lasztonya „Borshely-árok” LY1 (KeveY 2008: 44/1. táblázat). Lispeszentadorján „Diós-völgy” LY1 (Kevey 2008: 44/1. táblázat). 9466/4: Bánokszentgyörgy „Haraszti-erdő” K2, K5 (K: 2008). 9468/1: Újudvar „Csibiti-völgy” LY1 (K: 2006). 9468/2: Zalakaros „Kanica-erdő” K2, K5 (K: 2006). 9468/4: Zalakaros „Szőlő-hegy” K2, K5 (K: 1991). 9566/1: Zajk „József-hegy” K2, K5 (K: 2009), „Fintafai-erdő” K2, K5 (K: 2009). 9566/2: Valkonya „a Valkonyai-patak melletti erdőben” K2 (K: 2008). Zajk „József-hegy: a Béci-patak melletti erdőben” K2 (K: 2009). 9567/2: Sormás „Sormásierdő" K1a (K: 2016). 9667/2: Belezna „Szaplányosi-erdő” J5, K1a (K: 1987). 9668/1: Liszó „Medvés” K2, K5 (K: 1988). 9668/2: Iharosberény „Szentpáli-erdő” K2, K5 (K: 1987). BS: 9469/3: ZalakomárOrmándpuszta „Csöngő-kút” J5 (K: 1989). 9470/4: Marcali „Kis-Gyóta” J2, J5, J6 (K: 1994), „NagyGyóta” J5, J6, K1a (K: 1994). 9570/4: Böhönye-Dávodpuszta „Tranglus-erdő” J5, K1a (K: 1993), „Halászház” J5, K1a (K: 1991). 9571/1: Nagybajom „Lencsenpuszta és Szili-Bükk között” J5, K1a (K: 1992). 9571/3: Nagybajom „Fehér-tó” J5, K1a (K: 1996), „Felső-Csikotai-erdo” J5, K1a, K5 (KEVEY 
2013a: 24). 9669/4: Somogyszob „Bükki-malom” J5, K1a, K5 (K: 1998). 9770/3: Nagyatád „Ámorerdő” J6, K1a (K: 1984). 9771/1: Nagykorpád „Mórici-erdő” J5, K1a (K: 2017). 9771/3: Mike „Patkány-domb” J5, K1a (K: 1996). 9871/2: Kőkút „Babancsik” J5, J6 (K: 1996). Zs: 9672/3: Szenna „Derék-hegy” K2 (K: 2008). 9673/3: Cserénfa „Alja-patak” LY1 (KEvEY 2010: 34; KeveY 2013c: 35). Sántos „Öreg-hegy” LY1 (KEVEY 2010: 34; KEVEY 2013c: 35), „Herceg-forrás” J5, LY1 (K: 2010). Kaposvár „Nádasdi-erdő: Vas-kapu” LY1, K1a, K5 (Kevey 2010: 34; KeVEY 2013c: 35). 9673/4: Szentbalázs „Kóta” J5, J6 (K: 2004). 9674/2: Dombóvár-Szőlőhegy „Nyerges-erdo”” J5, K2 (K: 1994). 9772/1: Szenna-Lipótfa „Cseberki-erdo”” J5, K2 (K: 2010). 9772/2: Bőszénfa „Ropoly” K1a, K5 (K: 2004). 9772/3: Szenna „Dennai-erdő” J5, J6, K1a (K: 2009). 9773/1: Cserénfa „Tótfalusi-erdő” J5, J6, K1a (K: 2017). Gálosfa „Vörösalma-erdő” J5, J6, K1a (K: 2016). 9773/3: Almamellék „Sas-rét” J5, K5 (K: 2011). 9774/1: Baranyajenő „Öreg-hegy” K2, K5 (K: 2000). 9774/3: Palé „Nagy-hegy” K1a, K2 (K: 1984). V: 9775/1: Kisvaszar „Bikági-völgy” J5, J6, K1a (K: 2009). Mcs: 9776/2: Váralja „Farkas-árok” J6, LY1 (K: 2010). 9875/2: Komló „Gesztenyés” J6 (K: 2000), „Budafai-völgy” J5 (K: 1999). 9875/4: Pécs-Vasas „Galambos” J5 (Kevey \& BARANYI 2002: 15). Gd: 9777/3: Ófalu „Arany-völgy” LY1 (K: 1999). Szd: 9677/4: Szálka „Felső-erdő” J6 (K: 1988).

Dryopteris expansa (C. Presl) Fraser-Jenk. Mm: 8968/4: Dabronc „Ötvösi-erdő” K1a (K: 2009). BSzs: 7701/3: Beregdaróc „Dédai-erdő” K1a (K: 2003). 7801/1: Beregdaróc „Csere-erdő” K1a (K: 2009). Má: 9465/3: Tornyiszentmiklós „Mura-erdő” K1a, K5 (K: 2006). 9667/1: Murakeresztúr „Gyurgyánc” K1a (K: 2007). SDs: 9969/4: Babócsa „Dékány” K1a (K: 2004), „Mérus-erdő” (KEVEY 2007a: 88). BS: 9771/1: Nagykorpád „Mórici-erdő” K1a (K: 2017). Zs: 9673/3: Szentbalázs „Hercegképe” J5, K1a (K: 2017). 9772/2: Bőszénfa „Ropoly” J5 (K: 2003). Mcs: 9775/2: Ág „Vágyom-völgy” LY1 (K: 1997). 9776/3: Magyaregregy „Cikói-völgy” J5 (K: 2011). 9875/3: Pécs „Páfrányos” LY1 (K: 2004). Gd: 9777/4: Bátaapáti „Nagy-Mórágyi-völgy” LY1 (K: 2003). Khg: 9169/2: Zalaszántó „Vár-berek” J5 (K: 1988). Egyetlen tő!

Dryopteris filix-mas (K.) Schott - H: 8169/4: Újrónafo „Krisztína-berek” J6 (K: 2001). 9368/4: Osli „Tölös-erdő” K1a (K: 2001). R: 8567/4: Csáfordjánosfa „Csáfordi-erdő” J6, K1a (K: 2003). Mm: 8770/1: Dáka „Tilos-erdő” J6, K1a (K: 2012). 8870/3: Tüskevár „Tüskevári-erdő” J6, K1a (K: 2011). Mf: 8678/4: Martonvásár „Kastély-park” J6 (Kevey 1987b: 38). 9278/3: Bikács-Kistápé „Dombi-rét” L5 (KEVEY et LENDVAI in KEVEY 2015c: 21). 9278/4: Németkér „Körtvélyesi-erdő” K1a, L5 (KeveY in Kevey et Lendvai 2015: 23). 9378/1: Vajta „Nagy-erdő” K1a (KeveY in KeveY et Lendvai 2015: 23). Bikács-Kistápé „Tölgyfamajor” J6 (Kevey 2015c: 21), „Csordamező” K1a (KeveY in KeveY et LendvaI 2015: 23), „Ökör-hegy” L5 (Kevey 2015c: 21). 9378/2: Paks-Gyapa „Cseresznyés” K1a (Kevey et LENDVAI 2015: 23). 9378/3: Nagydorog „Banai-erdő” L5 (KeveY in KeveY et LendVAi 2015: 23). DTk: 9481/3: Kecel „Berek-erdő” J2 (K: 2017). 9381/2: Tabdi „Tabdi-erdő” J2 (K: 2004). Tv: 8881/2: Dabas „Turjános” J2 (K: 2016). Bk: 7695/4: Sátoraljaújhely „Long-erdő” J6, K1a (K: 2007). 7697/1: Pácin „Mosonnai-erdő” J6, K1a (K: 2008). 7697/4: Ricse „Lakonyai-erdő” J6 (K: 2008). Bszs: 7899/4: Vásárosnamény-Ugornya „Bagiszeg-erdő” J6 (K: 2009). 7900/2: Kisar „Tiszaártér” J4 (K: 2011). 7903/1: Magosliget „Cserköz-erdő” K1a (K: 2003). Ny: 8100/3: Mérk „Vadaskerti-erdő” J6, K1a (KeveY et al. 2017a: E1. Táblázat). Tiborszállás „Ezüsttábla” J6, K1a (KeveY in KeveY et al. 2017a: E1. táblázat). SDs: 9868/2: Somogyudvarhely „Vecsenye” J5, J6, K1a (Kevey 2007a: 91). 9869/3: Bélavár „Bereki-erdő” J6, K1a (Kevey 2007a: 91). BDs: 0275/2: Matty „Vittyás-erdo”” J4 (KeVEY \& TóTH V. 2006: 55). Khg: 9169/3: Cserszegtomaj „Csóka-kő” LY1 (K: 1999). 9269/2: Gyenesdiás „Büdöskúti-völgy” K2 (K: 1986). Ba: 8770/4: Kúp „Kúpi-erdő” J5, J6, K1a (K: 1989). ÉZ: 9166/3: Böde „Olátnok” LY1 (K: 2005). 9168/4: Nagykapornak „Remete-völgy” K2, K5 (K: 1992). 9268/1: Rádó „Büki-erdő” K2, K5 (K: 1992). DZ: 9467/3: Eszteregnye-Obornak „Márki-erdő” K2, K5 (K: 1986). 9468/2: Zalakaros „Kanicaerdő” K2, K5 (K: 2006). BS: 9469/3: Zalakomár-Ormándpuszta „Csöngő-kút” J5, J6 (K: 1989). 9471/3: Libickozma „Kopári-erdő” K1a (Kevey 2013a: 28). 9570/2: Mesztegnyő „Búsvár” J5, K1a (KeVEY 2013a: 28), „Dávodi-tó és Soponyai-tó között” J5, K1a, K5 (Kevey 2013a: 28). 9571/3: Nagybajom „Felső-Csikotai-erdő” J5, K1a, K5 (KeveY 2013a: 28), „Fehér-tó” J5, K1a, K5 (K: 1992). 9771/1: Nagykorpád „Mórici-erdő" J5, K1a (Kevey 2013a: 28). KS: 9372/4: Gamás „Vadéi-erdő” J5 (K: 1977). 9375/4: Tamási „Likas-hegy” K1a (K: 1981). 9472/1: Somogyvár „Télizöld” J5, K2 (K: 1998). Th: 9277/3: Kisszékely „Babaszó” K1a, L5 (K: 2017). 9377/1: Kiszékely „Dukai-hegy” K1a, L5 (K: 2017). Nagyszékely „Gyánti-lap” K1a (K: 2016).

Equisetum hyemale L. - Zs: 9873/4: Bükkösd „Sormás-patak” J6 (K: 2018). SDs: 0071/3: Drávatamási „Szigecske” J4 (K: 2018). 9969/2: Vízvár „Kerep” J4 (K: 2018).

Equisetum telmateia Ehrh. - DTk: 9680/2: Hajós „Sasfészek” (K: 2018). Mh: 9770/1: Ötvöskónyi „Alsóbogáti-erdő" J5 (K: 1996). 
Phegopteris connectilis (Michx.) Watt - Vh: 8967/1: Kám „Jeli Arborétum” K2 (K: 1990). Mcs: 9875/3: Pécs „Remete-rét”. Egyetlen példány! (Kurucz G. ined.: 1998).

Polypodium vulgare L. - DZ: 9667/4: Surd „Bükkfakúti-erdő” K2 (K: 1987).

Polystichum setiferum (Forssk.) Woyn. - Mh: 9770/1: Ötvöskónyi „Alsóbogáti-erdő” K1a (K: 1996).

\section{Dicotyledonopsida}

Adoxa moschatellina L. - DZ: 9667/4: Surd „Bükkfakúti-erdő” K1a (K: 1987). 9668/1: Miklósfa „Jankókúti-erdő" K1a (K: 1987).

Anemone nemorosa L. - DZ: 9668/1: Miklósfa „Jankókúti-erdő” K1a (K: 1987). Mcs: 9875/3: M: Mánfa „Petnyák-völgy: Ágnes vízesés”. Egyetlen mintegy $60 \mathrm{~cm}$ hosszú populáció! (Baranyai ex verb.: 2018).

Anemone ranunculoides L. - Sz: 8272/3: Vének „Somos-erdő” J6 (K: 1987). 8272/4: Vének „Somoserdő” J6 (K: 1987). Ghv: 8373/1: Bőny „Bőnyi-erdő” J6, K1a (K: 2005). H: 8269/3: Jánossomorja „Hanság-Nagy-erdő” J6 (K: 2001). R: 8468/2: Babót „Babóti-erdő” K1a (K: 2005). 8668/2: Kenyeri „Nasici-erdő” J6 (K: 2004). Kv: 9465/1: Kerkateskánd „Nagyszigeti-erdő” J6 (K: 2011). 9465/2: Kerkateskánd-Szécsi-sziget „Berek-erdő” J6 (K: 2011). Iklódbördöce „Cserta-erdő” K1a (K: 2010), „Cserta-torkolat” K1a (K: 2011). Mv: 9667/1: Murakeresztúr „Gyurgyánc” K1a (KeveY in KeveY \& KovÁcs J. A. 2010: 211). SDs: 9869/1: Somogyudvarhely „Vecsenye” J6, K1a (Kevey 2007a: 91). 9869/3: Somogyudvarhely „Almási-erdő” J6, K1a (KEVEY 2007a: 91). Bélavár „Palinai-erdő” J6, K1a (KeVEY 2007a: 91), „Bereki-erdő” J6, K1a (KEvEY 2007a: 91). BDs: 0274/1: Hirics „Dráva-ártér” J4 (K: ined.: 1998). 9973/3: Botykapeterd „Botykai-erdő” K1a (Kevey 2007b: 47). Mm: 8869/2: Kiscsősz „Nagy-erdő” K1a (K: 2009). 8969/1: Megyer „Balozsai-erdő” K1a (K: 2012). 9069/1: Zalagyömörő „Nyirlaki-erdő” J6 (K: 2012). BSzs: 7899/2: Vásárosnamény-Ugornya „Bagiszeg-erdő” J6 (K: 1979). 7899/4: Vásárosnamény-Ugornya „Bagiszeg-erdő” J6 (K: 1979). 7901/2: Kömörő „Páskom” J6, K1a (K: 2003). Bk: 7697/4: Ricse „Sása-szög” J6 (K: 2008). DTk: 9081/2: Kunadacs „Birkajárási-Új-erdő” K1a (RÉDEI ex verb.: 2018). Tv: 8781/1: Ócsa „Nagy-erdő” J6, K1a (K: 2015). 8781/2: Ócsa „Ómérerdő” J5, J6 (K: 2015). 8781/3: Dabas „Cibaktanya” J6 (K: 2015). Cssz: 8679/2: Érd „Sziget” J6 (K: 1997). 8779/3: Szigetújfalu „Újfalusi-erdő” J6 (K: 1978). 8779/4: Szigetújfalu „Újfalusi-erdő” J6 (K: 1978). 8879/1: Ráckeve „Silling-erdő” J6 (K: 1978). 8879/3: Ráckeve „Besnyo”” J6 (K: 1988). 8979/1: Makád „Rókás” J6 (K: 1989). Sk: 9779/3: Decs „Keskeny-erdo”” J6 (KeveY \& Tóth I.: 2000: 133). Zm: 8577/3: Alcsútdoboz „Csaplári-erdő” L5 (Kevey \& Simon Gy. ined.: 2009). 8577/4: Alcsútdoboz „Csaplári-erdő” L5 (Kevey \& Simon Gy. ined.: 2009). 8676/3: Zámoly „Csapás-völgy” L5, K1a (Kevey \& Lendvai ined.: 2008). 8676/4: Zámoly „Csapás-völgy” L5, K1a (Kevey \& Lendvai ined.: 2008). 8677/2: Vál „Váli-erdő” L5 (Kevey \& Simon Gy. ined.: 2010). 8677/4: Vál „Váli-erdo” L5 (Kevey \& Simon Gy. ined.: 2010). Mf: 8678/4: Martonvásár „Kastély-park” J6 (KeveY 1986: 38). 8877/4: Seregélyes „Kastély-park” J6 (K: 1997). 8976/4: Soponya-Nagyláng „Kastély-park” J6, K1a (K: 1981), „Fácánoserdő” J6 (K: 1978). 8977/1: Aba-Felsőszentiván „Szentiváni-erdő” J6 (K: 1993). 9177/3: PusztaegresŐrspuszta „Halastói-erdő” J6 (K: 1984). 9278/4: Németkér „Barát-erdő” K1a (LENDVAI in KEVEY \& LENDVAI 2015: 23). 9478/1: Kajdacs „Kiskajdacsi-erdő” J5, J6, K1a (Kevey \& Lendvai ined.: 2007). Bds: 8365/2: Sopron „Kő-hegy” K2 (K: 1979). Vh: 8968/1: Hosszúpereszteg „Szajki-tavak” K1a (K: 1991). A: 8566/2: Sopronhorpács „Kastély-park” J6 (K: 1979). 8665/4: Gencsapáti „Aponyi-park” K1a (K: 1998). Khg: 9269/2: Balatongyörök „Kígyós-völgy” K2 (K: 1986). Ba: 8672/2: Fenyőfő „Kuruc-erdő” K1a, L5 (KeVEY 2014: 60). B: 8771/4: Németbánya-Iharkút „Sármás” J5, K2 (K: 2015), „a Bittva-patak melletti erdőben” J5, K2 (K: 2017). 9070/3: Lesenceistvánd „Kisbakonyi-erdő” K1a (K: 2001). ÉZ: 9068/4: Vindornyaszőlős „Felső-erdő” K1a (K: 1993). 9267/4: Zalaszentmihály „Sinkei-erdő” J6 (K: 2012). 9268/3: Pacsa „Beláka” K2 (K: 1976). DZ: 9367/1: Söjtör „Fúró-hegy” LY1 (K: 1985). 9465/2: Tormavölde „Vétyemi-erdő" LY1, K5 (KeveY 2008: 44/6. táblázat). 9468/1: Újudvar „Csibiti-völgy” LY1, K2, K5 (K: 2006). 9468/2: Zalakaros „Kanica-erdő” K2, K5 (K: 2006). 9468/3: Újudvar „Dalasioldal” K5 (K: 2006). 9468/4: Zalakaros „Szőlő-hegy” K2, K5 (K: 1991). 9566/2: Valkonya „Valkonyaipatak” K2, K5 (K: 2008). 9567/2: Sormás „Sormási-erdő” K1a (K: 2015). Hosszúvölgy „Zsigárdi-erdő” J6, K1a (K: 2015). 9568/2: Zalaszentjakab „Sajci-erdő” J5 (K: 1986). 9568/4: Nagyrécse „Virág-hegy” K2, K5 (K: 1986). 9667/3: Belezna „Sándor-hegy” J5, J6, K1a (K: 2016). 9667/4: Surd „Bükkfakútierdő” K2 (K: 1987). 9668/1: Liszó „Medvés” K2, K5 (K: 1987). 9668/2: Iharosberény „Ágneslakierdő” K2, K6 (K: 1987), „Szentpáli-erdő” J6, K2, K5 (K: 1987). Mh: 9770/1: Ötvöskónyi „Alsóbogátierdő” K1a (K: 1996). BS: 9369/2: Balatonszentgyörgy „Battyán-erdő” J6 (K: 2017). 9469/3: 
Zalakomár-Ormándpuszta „Csöngő-kút” J5, J6 (K: 1989). Szőkedencs „Csörgető” J6 (K: 1999). 9470/4: Marcali „Kis-Gyóta” J6, K1a (Kevey 2013a: 28), „Nagy-Gyóta” J6, K1a (Kevey 2013a: 28). 9471/3: Libickozma „Kopári-erdő” K1a (KeveY 2013a: 28). 9569/1: Galambok „Vincédi-erdő” J6, K1a (K: 2014). Somogysimonyi „Gödörberki-erdő” J5, J6 (K: 1998). 9568/2: Galambok „Sagoti-erdő” J6 (K: 1988). Zalaszentjakab „a vasútállomás melletti erdőben” J6 (1989). 9769/3: Szenta „Kiskunovica” J5, K1a (K: 1982). 9769/4: Nagyatád „Döbrögi-erdő” K1a (KeveY 2013a: 28). 9770/2: Nagykorpád „Mórici-erdő" J5, K1a (Kevey 2013a: 28). 9771/1: Nagykorpád „Mórici-erdő” J5, K1a (KevEY 2013a: 28). KS: 9575/2: Döbrököz „Hajagos-erdő” J6 (K: 1994). Th: 9376/2: Nagyszékely „Kalános-erdő” K1a (K: 2014). V: 9575/4: Kurd „Szentkúti-erdő” J6 (K: 2013). Bd: 0075/2: Egerág „Halastói-erdő” K1a (K: 2013). 0075/3: Turony „Sziget” K2 (K: 2010). Gd: 9778/3: Mórágy „Pince-hegy” J6 (K: 2012). 9877/3: Geresdlak „Kisgeresdi-erdő” K1a (K: 2004). Szd: 9678/3: Szekszárd „Gurovica” K2 (Kevey \& Tóth I. Zs. ined.: 1989). 9778/1: Szálka „Rác-erdő” J5, K1a (K: 1990). Mcs: 9874/3: Bakonya „Sásvölgy” J5, K1a (KeveY 2015d: 24). Hetvehely „Sás-völgy” J5, K1a, K2 (K: 1978), „Nyáras-völgy” J5, K1a (K: 1979). Bükkösd „Pajtner-völgy” K2, K5 (KeveY 2015d: 24). Vlhg: 0075/4: Bisse „Poszhagymás” J6, K1a, K2, K5 (KeveY 1987: 1. táblázat).

Aruncus dioicus (Walter) Fernald - DZ: 9667/2: Liszó „Medvés” K2, K5 (K: 1988).

Asarum europaeum L. - Ghv: 8372/2: Bőny „Bőnyi-erdo”” J6, K1a (K: 2005). Mm: 8869/4: Tüskevár „Tüskevári-erdő" J6, K1a (K: 2011). Apácatorna „Galsai-erdő” J5, J6, K1a (K: 2013). 9069/1: Zalagyömörő „Nyirlakpusztai-erdő” J6, K1a (K: 2012). Mf: 8976/4: Soponya-Nagyláng „Park-erdő” J6, K1a (KeveY 1983: 20). Msz: 0078/3: Kölked „Alsó-Béda” J6 (LÁJER ex litt.: 2008). 0079/3: HercegszántóKarapancsa „Kastély-erdő” J6 (TóTH I. in Kevey et al:: 1992a: 15). SDs: 9869/1: Somogyudvarhely „Vecsenye” J6, K1a (Kevey 2007a: 91). 9869/3: Somogyudvarhely „Almási-erdő” J6, K1a (KeveY 2007a: 91). Bélavár „Bereki-erdő” J6, K1a (Kevey 2007a: 91). Vh: 8868/1: Káld „Avas-erdő” K1a, K2, K5 (K: 1983). B: 8771/2: Bakonyjákó-Iharkút „Sármás” J5, K2, K5 (K: 2015). 8772/1: Bakonybél „Gát-hegy” K2, K5 (K: 2012), „Gerence-völgy” J5, K5, LY1, LY2 (K: 2012), „Hideg-hegy” K2, K5, LY2, LY2 (K: 1998), „Várvölgy” K5, LY2 (K: 2015). Vr: 8476/4: Tatabánya-Felsőgalla „Vadorzó-árok” K2, K5 (K: 1983). DZ: 9467/1: Bucsuta „Börzöncei-hegy” K1a, K2, K5 (K: 2009), „Guricsányi-erdő” K1a, K2, K5 (K: 2009). 9468/1: Újudvar „Csibiti-völgy” K2, K5, LY1 (KEvEY 2008: 44/4. táblázat). 9668/4: Csurgónagymarton „Gágyi-erdő” K2, K5 (K: 2012). Mh: 9570/2: Mesztegnyő „Halastói-parkerdő” K1a, K2, K5 (K: 1993). 9570/3: Szenyér „Sári-csatorna” J5 (K: 2001). BS: 9369/2: Balatonszentgyörgy „Battyán-erdő” J6 (K: 2017). 9469/3: Szőkedencs „Nyugati-erdő” J6 (K: 1998). 9469/4: Szőkedencs „Csörgető” J6 (K: 1998). 9569/1: Somogysimonyi „Gödörberki-erdő” J5, J6 (K: 1998). 9570/2: Mesztegnyő „Dávodi-tó és Soponyai-tó között” J6, K1a, K5 (KEVEY 2013a: 28), „Búsvár” J5, K1a (K: 1991). 9571/3: Nagybajom „Fehér-tó” K1a, K5 (K: 1988), „Lencsenpuszta és Szili-bükk között” K1a (KEVEY 2013a: 28), „FelsőCsikotai-erdo”" J5, K1a, K5 (KEveY 2013a: 28). 9769/3: Szenta „Kiskunovica” J5, K1a (K: 1982). 9769/4: Szenta „Döbrögi-erdő” K1a (Kevey 2013a: 28). 9771/1: Nagykorpád „Mórici-erdő” J5, K1a (Kevey 2013a: 28). KS: 9471/2: Somogyvár „Park-erdő” K2 (K: 1997). 9472/1: Somogyvár „Télizöld” J5, K2 (K: 1998). 9575/2: Döbrököz „Hajagos-erdő” K1a (K: 1994). Mcs: 9776/3: Magyaregregy „Máré-vár” K2, K5 (KEVEY 2012a: 37), „Cikói-völgy” J5, K2, K5 (KevEy 2012a: 37), „Akai-tető” K2, K5 (KEvEY 2012a: 37). Szászvár „Somlyó” K2, K5, LY2 (KeveY 2012a: 37). Vékény „Miklós-vár” K2, K5, LY2, LY4 (KeveY 2012a: 37), „Somos” K2, K5, LY2, LY4 (KeVEY 2012a: 37).

Cardamine amara L. - Mh: 9770/1: Ötvöskónyi „Alsóbogáti-erdő” K1a (K: 1996).

Cardamine bulbifera (L.) Crantz - Zm: 8676/4: Zámoly „Csapás-völgy”! K1a (HoRvÁth A. ined.: 2009). Mm: 8869/2: Kiscsősz „Nagy-erdő” K1a (K: 2009). 8869/4: Apácatorna „Galsai-erdő” J5, J6, K1a (K: 2013). Karakószörcsök „Felső-erdő” K1a (K: 2013). Tüskevár „Tüskevári-erdő” J6, K1a (K: 2011). 8870/1: Somlóvásárhely „Lovas-erdő” J6, K1a (K: 2013). Doba „Felső-erdő” J6, K1a (K: 2005). Mf: 9377/2, 9378/1: Vajta „Nagy-erdő” K1a, L5 (KEVEY \& LENDVAI 2015: 23). 9378/2: Németkér „Látóhegy” K1a, L5 (Kevey in Kevey \& Lendvai 2015: 23). SDs: 9868/2: Somogyudvarhely „Vecsenye” J6, K1a (Kevey 2007a: 91). 9869/3: Bélavár „Bereki-erdő” J6, K1a (Kevey 2007a: 91), „Palinai-erdő” J6, K1a (Kevey 2007a: 91). BDs: 0073/1: Sumony „Sumonyi-erdo” K1a (K: 1988). Zm: 8676/3: Zámoly „Csapás-völgy” K1a, L5 (Horváth A. ined.: 2008). Ny: 7998/4: Baktalórántháza „Baktai-erdő” K1a (KeveY in Kevey et al. 2017a: E1-2 táblázat). 8299/1: Nyírvasvári „Csonkai-erdő” J6, K1a (Kevey in KEVEY et al. 2017a: E1-2 táblázat). BSzs: 7801/1: Beregdaróc „Csere-erdő” K1a (K: 2009). Bds: 8365/2: Sopron „Kő-hegy” K2 (K: 1981). Vh: 8968/3: Mikosszéplak „Mikosdi-erdő” K1a, K2 (K: 1991). Sd: 8572/1: Sokorópátka „Öreg-erdo” K2 (K: 2010). Ba: 8572/4: Gic „Gerencséri-erdő” J5 (Kevey 2015b: 62). 8672/1: Pápateszér „Mehetősi-erdő” J5 (KeVEy 2015b: 62). 8770/4: Kúp „Kúpi- 
erdő” J5, J6, K1a (K: 1989). 8870/2: Noszlop „Becsei-erdő” J5, K1a (K: 2002). Khg: 9269/2: Gyenesdiás „Büdöskúti-völgy” K2 (K: 1986). DB: 9070/3: Lesenceistvánd-Uzsa „Kisbakonyi-erdő” K1a (K: 2001). ÉZ: 9166/3: Böde „Olátnok” LY1 (K: 2005). 9268/1: Nagykapornak „Alsó-erdő” K2, K5 (K: 1992). Rádó „Büki-erdő” K2, K5 (K: 1992). DZ: 9468/1: Újudvar „Csibiti-völgy” K2, K5, LY1 (KevEY 2008: 44/4. táblázat). 9468/3: Újudvar „Dalasi-oldal” K5 (K: 2005). 9567/2: Hosszúvölgy „Zsigárdierdő” J6, K1a (K: 2015). 9568/2: Nagyrécse „Rák-patak” J5 (K: 1986). 8568/3: Bagola „Bagolai-erdő” K2 (K: 2015). Mv: 9667/1: Murakeresztúr „Gyurgyánc” J6, K1a (KevEY \& KovÁcs J. A. 2010: 212). BS: 9469/3: Szőkedencs „Csörgeto”” J6 (K: 1999). 9469/4: Csákány „Hertelendi-erdő” J6, K1a (K: 1998). 9470/4: Marcali „Kis-Gyótai-erdő” J6, K1a (KeveY 2013a: 28), „Nagygyótai-erdő” J6, K1a (KeveY 2013a: 28). 9769/3: Szenta „Kiskunovica” J5, K1a (K: 1982). 9769/4: Szenta „Döbrögi-erdő” K1a (Kevey 2013a: 28). 9771/1: Nagykorpád „Mórici-erdő” J5, K1a (KeVEY 2013a: 28). KS: 9472/1: Somogyvár „Télitöld” J5, K2 (K: 1998). 9575/2: Döbrököz „Hajagos-erdő” K2 (K: 1994). Th: 9277/3: Kisszékely „Kis-erdő” K1a, L5 (K: 2011), „Babaszó” (K: 2017). 9376/2: Nagyszékely „Gyánti-lap” K1a (Kevey \& HoRváth A. ined.: 2016). Zs: 9674/2: Dombóvár „Nyerges-erdő” J5, K2 (K: 1994). 9874/1: Kisbeszterce „Pusztaszőlősi-gödör” J5 (K: 2012). Mcs: 9874/3: Bakonya „Sás-völgy” J6, K1a, K2, K5 (KEVEY 2015d: 23). Bükkösd „Meleg-mál” K2 (KEVEY 2015d: 23).

Carpesium abrotanoides L. - Zs: 9772/2: Zselickisfalud „Tergócs-erdő” J6 (K: 2018).

Carpesium cernuum L. - Zs: 9772/2: Zselickisfalud „Tergócs-erdő” J6 (K: 2018). 9772/4: Somogyhárságy-Kishárságy „Enyezdi-erdő” K2 (J: 2018).

Dianthus barbatus L. - Zd: 9767/2: Őrtilos „Földvári-hegy” M8 (K: 1998).

Doronicum orientale Hoffm. - Gd: 9877/2: Bátaapáti „Fenyves-tető”! L2a (TóTH I. Zs. in KEVEY 1988a: 97).

Eranthis hyemalis (L.) Salisb. - A: 8566/2: Sopronhorpács „Kastélypark” J6 (K: 1998). 8667/3: Szeleste „Arborétum” J6 (K: 1998). Mindkét helyen ültetve! KS: 9575/2: Döbrököz „Hajagos-erdő” K1a (K: 1988). Mf: 8976/4: Soponya-Nagyláng „Fácános-erdő” J6 (HoRvÁT A. O. et KEVEY ined.: 1974), „Kastélypark” J6, K1a (K: 1980). Káloz „Belmajor: Parkerdő” J6 (K: 1984). Mindhárom helyen ültetve, vagy kivadulva!

Fagus sylvatica L. - DTk: 8584/3: Szentmártonkáta „Kastély-park”! K1a (URBÁN ined.: 2014).

Galeobdolon luteum Huds. - Mh: 9770/1: Ötvöskónyi „Alsóbogáti-erdő” K1a (K: 1996).

Galium rivale (Sibth. et Sm.) Griseb. - DTk: 9281/4: Soltszentimre „Kullér-erdő” (K: 2017). Tv: 8781/1: Ócsa „Ómér-erdő” (K: 2018).

Genista ovata Waldst. et Kit. - KS: 9173/4: Zamárdi „Todolai-erdő” L1 (K: 1977). Mcs: 9875/3: Pécs „Vörös-hegy” L1 (K: 1992), „Remete-rét” L1 (K: 1992), „Tubes” LY4 (K: 1992). Vlhg: 0175/2: SiklósMáriagyűd „Tenkes” L1, LY4 (Kevey 2012b: 50), „Csukma-hegy” L1, LY4 (K: 2013). Harkány „Tenkessarok" L1, LY4 (K: 2013).

Gnaphalium uliginosum L. - Sz: 8171/1: Lipót „Örök-sziget” J3 (KEVEY 2008: 18/3. táblázat). 8174/4: Ásványráró „Nagy-sziget=Ercséd” J3 (KeveY 2008: 18/3. táblázat), „Gyalap” J3 (K: 1991), „Töklevélsziget” J3 (Kevey 2008: 18/3. táblázat), „Madarász-sziget” J3 (KeVEy 2008: 18/3. táblázat). 8272/1: Nagybajcs „Robinzon-sziget” J3 (K: 1991).

Hottonia palustris L. - Tv: 8781/1: Ócsa „Nagy-erdő” (K: 2018). A térképen régi adatként van feltüntetve. Mivel jelenleg is él, a félig befeketített korong helyett fekete koronggal kell jelölni.

Isopyrum thalictroides L. - DZ: 9667/4: Surd „Bükkfakúti-erdő” K2 (K: 1987).

Lathraea squamaria L. - Tk: 7490/4: Bódvarákó „Esztrámos és Kis-hegy között” (K: 2018).

Limosella aquatica L. - Sz: 8171/1: Lipót „Örök-sziget” J3 (KEVEY 2008: 18/3. táblázat).

Omphalodes scorpioides (Haenke) Schrank H: 8367/3: Fertőd „Eszterházy Lés-erdő” K1a (K: 1987). R: 8468/1: Kapuvár „Rába-erdő” J6, K1a (K: 2005). 8668/1: Uraiúffalu „Kőréti-erdő” J6, K1a (K: 2014). 8867/3: Rum „Rumi-erdő” J6, K1a (K: 2003). Zsennye „Zsennyei-erdo” J6 (K: 2016). SDs: 9768/4: Csurgó „Lankóci-erdő” K1a (Kevey 2007a: 92). 9868/2: Somogyudvarhely „Vecsenye” K1a (Kevey 2007a: 92). 0071/3: Drávatamási „Szigecske” (K: 2018). Mm: 8870/3: Tüskevár „Tüskevárierdő” J6, K1a (K: 2011). Ba: 8870/4: Borszörcsök „Csigere-patak” J6, K1a (K: 2012). 8871/3: Devecser „Beréndi-erdo”” J6, K1a (K: 2005). 8672/2: Bakonyszentlászló „Pagonyi-erdő: Hódos-ér” J5 (KeveY 2015b: 63). B: 8672/2: Bakonyszentlászló „Cuha-völgy” LY1 (K: 1994). 8672/3: Bakonybél "Gerence-völgy” J5, LY1 (K: 2012). 8772/2: Bakonybél „Som-hegy” K5, LY2 (K: 2011). 8772/3: Bakonybél „Szömörke-völgy” J5 (K: 2012). 8873/1: Hárskút „Esztergály-völgy” K5, LY1 (K: 1999). 8873/2: Hajmáskér „Tobán-hegy” LY2, LY4 (K: 1995). DZ: 9465/2: Kerkateskánd „Berek-erdő” J6 (K: 2010). 9667/3: Belezna „Sándor-hegy” J6, K1a (K: 2016). Mcs: 9876/1: Hosszúhetény „Zengő” LY2, 
LY4 (K: 1983). Pécsvárad „Zengo” LY2, LY4 (K: 1983). Gd: 9777/3: Mecseknádasd „Borvicska-hegy lábánál” K1a (K: 2017). 9877/3: Geresdlak „Kisgeresdi-erdő” K1a (K: 2004).

Oxalis acetosella L. - DZ: 9667/4: Surd „Bükkfakúti-erdő” K2 (K: 1987).

Peltaria alliacea Jacq. - VRv: 8966/3: Egyházashollós „Hollósi-erdő” (Kevey 2005: 18). Az erdő két pontján egy-egy kicsiny populáció!

Primula vulgaris Huds. - Mh: 9770/1: Ötvöskónyi „Alsóbogáti-erdő” K1a (K: 1996).

Ranunculus auricomus agg. - DTk: 9680/2: Hajós „Sasfészek” (K: 2018).

Ranunculus lingua L. - Sz: 8271/1: Győrladamér „Holt-Duna” J1a (K: 1998).

Urtica kioviensis Rogow. - Tv: 8781/1: Ócsa „Nagy-erdő” (K: 2018). Mivel e helyen ma is él, a térképen a félig fekete korong helyett fekete koronggal jelölendő.

\section{Monocotyledonopsida}

Allium atroviolaceum Boiss. - HNs: 0077/1: Bóly „a nagynyárádi műút mellett” OF (K: 2002).

Allium carinatum L. - Mm: 8770/1: Dáka „a Tilos-erdő szélén” M8 (K: 2010). Khg: 9169/2: Rezi „Pörkölt-hegyek” M8 (K: 1987).

Allium suaveolens Jacq. - Tm: 9170/2: Tapolca „Kis-Berki” D2 (K: 1970).

Allium ursinum L. - Sz: 8170/1: Máriakálnok „Ásvány” J6 (K: 1988). 8271/1: Mecsér „Sziget-erdő” J6 (K: 1988). 8272/4: Vének „Kolera-sziget” J4 (K: 1991). Csak néhány példány! Is: 8467/1: Röjtökmuzsaj „Lövői-domb” K1a (Király G. ined.: 2004). R: 8468/4: Mihályi „Park-erdő: a Kis-Rába hidjánál” (Király G. ined.: 2005). 8569/2: Szany-Rábaszentandrás „Szentandrási-erdő” J5, J6 (Bancsó \& Keszei ined.: 1998). KTv: 9486/4: Baks „Süli-erdo”” J6 (ARADI, BÁTORI, CSEH, ERDős, HoRvÁth D., PATAKI, TÖLGYESI in BÁtori et al. 2014: 96). J: 8383/1: Verseg-Fenyőharaszt „Kastély-park”! J6 (ZóLYomI 1969: 215; KevEY 1979: 167). CsSz: (KÁRPÁTI I. \& KÁRPÁTI V. 1958: 314): 8779/3: Szigetújfalu (VAJDA L. BPM: 1954) „a Duna melletti erdőben” J6 (Boros ined.: 1954; BoRos 1970: 71) = „Újfalusi-erdő”! J6 (VAJDA L. ined.: 1954). Ezt a lelőhelyet VAJDA L. (ined.: 1974) „Silling-erdő” néven jegyezte fel (KEVEY 1979: 167), de a Silling-erdő már Ráckeve határában fekszik, ezért a dűlőnevet javítottam. 8879/1: Ráckeve „Szigetújfalu és Lórév között” = „Silling-erdő” J6 (Kevey 1979: 167). 8879/3: Ráckeve „Besnyő” J6 (K: 1990). 8979/1: Lórév „a rév és Makád közötti erdőben”! J6 (GoTTHÁRD in KeveY 1979: 167). DTk: 9680/2: Hajós „Sasfészek” (K: 2018). Mindössze nyolc tő! Tv: 8781/1: Ócsa „Nagy-erdő” (K: 2018). Mintegy két m²-es területen. Msz: 0078/3: Kölked „Felső-Béda” (Deme ex verb.: ). A növény egy hétvégi ház becserjésedett kertjében van, ezért valószínúleg behurcolt! Mf: 8976/4: Soponya-Nagyláng „Fácános-erdő”! J6 (HANGAY 1889: 159; MoEsZ et JÁVorKa BPM: 1923; MOESZ et JÁvorKA in KeVEY 1979: 167), „Kastély-park” J6, K1a (K: 1981). HANGAY (1889: 159) szerint Festetics gróf honosította meg. 8678/4: Martonvásár „Kastély-park”! J5, J6, K1a (BoROS ined.: 1933; JÁVORKA BPM: 1954; JÁVORKA in KEVEY 1979: 167; KEVEY 1987b: 38). 9077/3: Ez a lelőhely törlendő. A Mezőföld maradványerdeit több mint 40 éve kutatom, de e területen a növényt nem láttam. Az adatszolgáltató (Horváth A.) sem tud az előfordulásról. Mv: 9465/3: Tornyiszentmiklós „Mura-erdő” K1a (KeveY in KeVEY \& KovÁcs J. A. 2010: 213). 9565/1: Murarátka „Mura-ártér” J4 (K: 2010). 9566/3: Letenye „Murcsek” J4 (Lelkes ex verb.: 2010). SDs: 9869/1: Somogyudvarhely „Zdálaierdő = Vecsenye” J5 (BoRHIDI 1958b: 357). BDs: 0273/1: Drávasztára „Nagy-füzes-erdő” (Wágner ex litt.: 1995). Khg: 9169/3: Cserszegtomaj „Csóka-kő” K2 (K: 2000). 9269/1: Keszthely „Helikon-park”! J6 (AlmádI et SzABó I. in Kevey 1979: 170). 9269/2: Gyenesdiás „Büdöskúti-völgy” K2 (SzABó I. in KeveY 1979: 169; K: 1986). Bf: 9270/2: Szigliget „Arborétum”! (PAPP J. in KevEY 1979: 169). Sd: 8472/3: Pannonhalma „Pap-erdő!! K2 (Galambos 1998: 96). Ravazd „Vadalmás”! K2 (Galambos 1998: 96). B: 8772/2: Bakonybél „Som-hegy”! LY2, K5 (KeRNER 1878: 148; K: 2011). 8873/3: Veszprém „Csatár-hegy” K2 (K: 1999). 9070/3: Lesenceistvánd-Uzsa „Kisbakonyi-erdő” K1a (K: 2001). P: 8379/1: Pilisszentkereszt „,a Nagyszoplák és a Pilis-hegy között”! K5 (HoRÁNSZKY in KEVEY 1979: 168), „a Vaskapuszurdoktól délre, a Lepke-barlang közelében”! LY2 (Stoflitz ined.: 1985). 8379/4: Csobánka „Csobánkainyereg” (BARINA 2008: 5), „volt gyümölcsösben egyetlen tő” (BARINA ex litt.: 2003). Bö: 7980/4: Hont „Kút-berek”! K2, K5 (Bezeczky ined.: 1998). K: 7884/3: Salgótarján-Somoskőújfalu „Erdészvölgy-dülő” K5 (Barina ex litt: 2016). Zh: 7494/3: Telkibánya „Nagy-hegy és Gyepű-hegy között”!! K2 (Molnár Cs. ex litt.: 2013), „Zöldmájtanya”! K2 (Pelles ex verb.: 2014). ÉZ: 9267/4: Zalaszentmihály „Sinkei-erdő” J6 (K: 2012). DZ: 9468/4: Zalakaros „Szőlő-hegy”! K2, K5, LY1 (Palkó ex verb.: 1990). 9568/2: Zalaszentjakab „Sajci-erdő” J5 (K: 1986). 9568/4: Nagyrécse „Virág-hegy” K2, K5 (K: 1974). 9667/2: Miklósfa „Szaplányosi-erdő” K1a, K2 (K: 1987). 9668/2: Iharosberény „Szentpáli-erdő” J6, K2, K5 (K: 1987). BS: 
9369/2: Balatonszentgyörgy „Battyán-erdő” J6 (K: 2017). 9469/3: Szőkedencs „Csörgető” J6 (K: 1998). Zalakomár-Ormándpuszta „Csöngő-kút” J5, J6 (K: 1989). 9469/4: Csákány „Hertelendi-erdő” J6, K1a (K: 1998). Somogyzsitfa-Szőcsénypuszta „Margit-sétány” J5 (K: 1996). 9471/1: Csömend „Koszód” J5, J6 (K: 1981). 9471/3: Libickozma „Kopári-erdő” K1a (KEVEY 2013a: 28). 9569/1: Somogysimonyi (BUDAVÁRI in KEVEY 1979: 171) „Gödörberki-erdő” J5, J6 (K: 1997). Galambok „Vincédi-erdő” J6, K1a (K: 2014). 9571/1: Mesztegnyő „Felső-Kak” J5, K1a, K5 (KeveY 2013a: 28). 9571/3: Nagybajom „Felső-Csikotaierdő” J5, K1a, K5 (KeVEy 2013a: 28). 9669/3: Somogyszob „Rinya-erdő” J5, K1a (BoRos 1925: 29; KeVEY 2013a: 28). 9669/4: Somogyszob „Bükki-malom” J5, K1a, K5 (Boros 1925: 29; KeVEY 2013a: 28), „Kővölgyi-erdő” J5, K1a, K5 (Kevey 2013a: 28). 9670/1: Böhönye „Csöprönd” K1a (K: 1997). 9769/3: Szenta „Kiskunovica” J5, K1a (BoRHidi 1958a: 108; K: 1975). 9770/3: Nagyatád „Ámor-erdő” J6, K1a (K: 1983). 9771/1: Nagykorpád „Mórici-erdő”! J5, K1a (Juhász ex litt.: 1984). 9771/3: Mike „Patkány-domb” J5, K1a (K: 1996). 9871/2: Kőkút „Babancsik” J5, J6 (K: 1996). 9970/3: Babócsa „romoknál” J5, J6 (Boros 1925: 29; K: 1974). Mh: 9570/1: Szenyér „Hedve”. K2 (K: 2014). 9570/3: Szenyér „Sári-csatorna” J5 (K: 2001). Nemeskisfalud „Szőlő-hegy” K2 (K: 2001). KS: 9472/1: Somogyvár „Télizöld” J5, K2 (K: 1997). Th: 9377/1: Kisszékely „Dukai-völgy” Csak néhány parányi foltban! J5, K1a (KEvEY 2015a: 51; Horváth A. ex verb.: 2016). Zs: 9674/2: Dombóvár-Szőlőhegy „Nyerges-erdő” J5, K2 (K: 1994). 9874/1: Kisbeszterce „Lipalagi-erdő” J5 (K: 2012). Bd: 0075/2: Egerág „Halastói-erdő” K1a (K: 2013). 9976/3: Olasz „Belvárdi-vízfolyás melletti erdő” (Gregorits ex verb.: 2016). 9977/2: Székelyszabar „Szabarierdő"! K1a (Gregorits ex verb.: 2010). Vlhg: 0075/4: Bisse „Poszhagymás” K1a, K2, K5 (KeVEY 1979: 172). Mcs: 9876/3: Hird „6-os csárda” J5 (K: 2006). V: 9575/4: Kurd „Szentkúti-erdő” J6 (Gál ex verb.: 2012). 9675/2: Nagyhajmás „Csábi-patak” K1a (Tóth I. Zs. ex litt.: 2005). 9775/1: Kisvaszar „Bikágivölgy” J5, J6, K1a, K2, K5 (Horvát A. O. et Kevey ined.: 1974). 9775/2: Ág „Vágyom-völgy” J6, K1a, K5, LY1 (Kevey \& Tóth I. Zs. ined.: 1991).

Asphodelus albus Mill. - BS: 9570/2: Mesztegnyő „Hosszúvíztől délre”! L2b (JuHÁsz M. in Kevey et al. 1992b: 32). 9571/1: Mesztegnyő „Mély-éger” L2b (NovACSEK et JuHÁsz M. in KEVEY et al. 1992b: 32).

Carex acuta L. - Sz: 8069/2: Dunakiliti „Közép-füzes” J4 (K: 1991), „Új-mérés” J4 (K: 1992). 8070/1: Dunasziget „Vörös-füzes” J4 (K: 1992), „Hosszú-televény” J4 (K: 1990), „Kormos” J4 (K: 1992). 8070/3: Dunasziget „Kerekes-ciglés” J4 (K: 1991), „Hajós-sziget” J4 (K: 1990), „Jakab-sziget” J4 (K: 1990). 8070/4: Kisbodak „Televény-sziget” J4 (Kevey 2008: 19/4. táblázat). 8169/2: Mosonmagyaróvár „Parti-erdő” J2 (K: 1988). 8170/2: Kisbodak „Öreg-sziget” J4 (K: 1990), „Alsósziget” J4 (K: 1991), „Pálfi-erdő” J4 (K: 1992). Dunaremete „Nagy-Duna” J3 (K: 1997). Lipót „Harmadik-erdő” J4 (K: 1991). 8171/1: Lipót „Új-sziget” J4 (Kevey 2008: 18/3. táblázat), „Öröksziget” J4 (KEVEY 2008: 17/3. táblázat). 8271/2: Győrzámoly „Nyelő-szeg” J4 (K: 1993), „Nagy-Patkó” J4 (K: 1996), „Medvei-erdő” J4 (K: 1993). 8271/4: Vámosszabadi „Erdőalja” J1a (K: 1998). 8272/1: Nagybajcs „Körtvélyes” J4 (K: 1991), „Robinzon-sziget” J3, J4 (KEVEY 2008: 18/3. táblázat), „Vörös-rét” J1a (KeveY 2008: 26/4. táblázat). 8272/3: Kisbajcs „Csápolnok” J1a, J4 (K: 1997), „Szavai-csatorna” J1a (K: 1997). 8272/4: Vének „Kolera-sziget” J3, J4 (KeVEY 2008: 21/4. táblázat). R: 8668/1: Uraiújfalu „Rába-ártér” J4 (K: 2016). VRv: 8867/3: Meggyeskovácsi „Rába-ártér” J4 (Kevey \& Barna ined.: 2016). Mv: 9566/1: Murarártka „Gálparlag” J4 (KevEY 2014: 42). SDs: 0069/2: Babócsa „Jelkus” J4 (K: 2008). 9767/2: Zákány „Sziget” J4 (K: 2011). BDs: 0171/2: Szentborbás „Csicsóka” J4 (KEVEY in Kevey \& Tóth V. 2006: 53). Cssz: 8680/1: Budapest „Háros-sziget” J4 (KeveY - Huszár 1999: 40). 8779/1: Százhalombatta „Kacsás-sziget” J4 (K: 1998). Sk: 9779/1: Decs „Nagy-Holt-Duna” J3 (KeveY in KeveY et al. 2006: 219; KeveY in KeveY et al. 2010: 223). 9779/3: Baja „Nagy-Rezét” J4 (K: 1994). Pörböly „Sugó” J4 (Kevey in Kevey et al. 2006: 219; KeveY in Kevey et al. 2010: 223). 9878/2: Báta "Gyürűsalj” J4 (Kevey in Kevey et al. 2006: 219; Kevey in Kevey et al. 2010: 223). 9879/1: Báta „Pusztaréti-erdő” J3 (K: 2004), „Nyéki-Holt-Duna” J3 (Kevey in Kevey et al. 2006: 219; KeveY in KeveY et al. 2010: 223). Baja „Csöröszi-lap” J3, J4 (Kevey in Kevey et al. 2006: 219; Kevey in Kevey et al. 2010: 223), „Megyehatári-rét” J3, J4 (Kevey in Kevey et al. 2006: 219; KeveY in KeveY et al. 2010: 223). Msz: 9978/2: Dunafalva „Csele-erdő” J4 (KevEY 2017b: E1. táblázat). Bszs: 7800/3: Jánd „Holt-Tisza” J3, J4 (Kevey \& BARna 2016: 90). 7901/1: Nagyar „Tisza-ártér” J4 (Kevey \& BARNA 2016: 90). Tivadar „Dorongó” J4 (KEVEY \& BARNA 2016: 90).

Carex pilosa Scop. - Mm: 8770/1: Dáka „Tilos-erdő” K1a (K: 2010). Ny: 8199/4: Terem „Nagyfenék” J6, K1a (K: 1994). DTk: 8984/1: Nagykőrös „Nagy-erdő: a Strázsa-domb közelében” (KeVEY et URBÁN ined.: 2018). Mf: 8976/4: Soponya-Nagyláng „Park-erdő” K1a (KeveY 1983: 22). 8977/1: Aba „Felsőszentiváni-erdő” J6 (K: 1999). HNs: 0077/3: Töttös „Töttösi-erdő” K1a (K: 2003). Khg: 9169/3: "Cserszegtomaj „Csóka-kő” K2 (K: 1999). 9170/1: Lesenceistvánd „Kú-orra” K2, K5 (K: 2014). 9269/2: 
Gyenesdiás „Büdöskúti-völgy” K2 (K: 1986). Ba: 8871/3: Devecser „Beréndi-erdő” K1a (K: 1992). B: 8671/4: Ugod „Somberek” K2, K5 (K: 2015). 8674/4: Bakonycsernye „Kisgyóni-erdő” K2, K5 (K: 2015). 9069/2: Csabrendek „Rendeki-hegy” K2 (K: 2001). Sümeg „Fehér-kövek” K2, K5 (K: 2005). G: 8377/1: Süttő „Kis-Gerecse” K2, K5 (K: 1995). Lábatlan „Pisznice” K2, K5 (K: 2008). NyergesújfaluPusztamarót „Vaddisznós” K2, K5 (K: 1995), „Kisbajót” K2 (K: 2009), „Mészberki-kút” K2 (K: 2008). ÉZ: 9068/3: Zalaistvánd „Tormási-erdő” K2, K5 (K: 1976). DZ: 9367/1: Söjtör „Fúró-hegy” LY1, K2 (K: 1985). 9466/1: Lasztonya „Borshely-árok” LY1, K2 (KeveY 2008: 44/5. táblázat), „Cigány-árok” LY1, K2 (Kevey 2008: 44/5. táblázat). 9467/1: Bucsuta „Börzöncei-hegy” K2, K5 (K: 2009). 9667/2: Miklósfa „Szaplányosi-erdő” K1a, K2 (K: 1987). 9668/1: Liszó „Medvés” K2, K5 (K: 1987). 9668/2: Iharosberény „Szentpáli-erdő” K2, K5 (K: 1987). 9668/4: Iharos-Ágneslak „Gágyi-erdo”" K2, K5 (K: 2012). Mh: 9770/1: Ötvöskónyi „Alsóbogáti-erdő” K1a (K: 1996). BS: 9369/2: Balatonszentgyörgy „Battyán-erdő" J6 (K: 2017). 9471/3: Libickozma „Kopári-erdő” K1a (K: 2008). 9569/1: Somogysimonyi „Gödörberki-erdő” J6, K1a (K: 1998). 9570/4: Böhönye-Dávodpuszta „Trangluserdő” K1a (KeVEY 2013a: 28). 9571/1: Mesztegnyő „Felső-Kak” K1a, K5 (KeVEY 2013a: 28). 9571/3: Nagybajom „Felső-Csikotai-erdő” K1a, K5 (KEVEY 2013a: 28). 9669/3: Somogyszob „Rinya-erdő” K1a (KeVEy 2013a: 28). 9669/4: Somogyszob „Kővölgyi-erdő” K1a, K5 (Kevey 2013a: 28). 9769/3: Szenta „Kiskunovica” K1a (K: 1982). 9770/3: Nagyatád „Ámor-erdő” J6, K1a (K: 1983). 9771/1: Nagykorpád "Mórici-erdő" K1a (Kevey 2013a: 28). KS: 9471/2: Somogyvár „Brézai-erdő” K2 (K: 1997). 9472/1: Somogyvár „Télizöld” K2 (K: 1998). 9575/2: Döbrököz „Hajagos-erdő” J6 (K: 1994). Th: 9277/3: Simontornya „Gyertyános” K1a, K2 (K: 2006).

Carex rostrata Stokes - Zd: 9767/2: Ốrtilos „Visszafolyó-patak” J2 (KeVEy \& Toldi 2013: 54).

Carex vesicaria L. - Sz: 8069/1: Rajka „Diós” J2 (K: 1992), „Középső-erdő” J5 (K: 1992). 8069/4: Mosonmagyaróvár „Parti-erdő” J2 (K: 1991). 8070/1: Dunasziget „Hosszú-televény” J4 (K: 1990). 8070/3: Dunasziget „Hajós-sziget” J4 (Kevey 2008: 19/4. táblázat), „Jakab-sziget” J4 (K: 1989). 8070/4: Kisbodak „Televény-sziget” J4 (Kevey 2008: 19/4. táblázat). 8170/2: Kisbodak „Öreg-sziget” J4 (Kevey 2008: 19/4. táblázat), „Alsó-sziget” J4 (Kevey 2008: 19/4. táblázat), „Pálfi-erdő” J4 (KeveY 2008: 19/4. táblázat). Lipót „Harmadik-erdő” J4 (KEvEY 2008: 19/4. táblázat). 8170/3: Darnózseli „Kimlei-sarok=Erdei-kert” J2 (K: 2000). 8170/4: Kimle „Novákszigeti-erdo”” J2 (K: 1995). Hédervár „Zsejkei-csatorna” J2 (K: 1992), „Vadaskerti-erdő” J2 (K: 1990). 8171/1: Lipót „Új-sziget” J4 (K: 1991). 8171/3: Ásványráró „Öntési-tó” J4 (KEvEY 2008: 19/4. táblázat). 8171/4: Ásványráró „Kövecses” J4 (Kevey 2008: 19/4. táblázat), „Gyalap” J4 (Kevey 2008: 19/4. táblázat), „Töklevél-sziget” J4 (Kevey 2008: 19/4. táblázat), "Madarász-sziget” J4 (KeVEY 2008: 19/4. táblázat). 8271/2: Győrzámoly „Nyelőszeg” J4 (K: 1993), „Medvei-erdő” J4 (K: 1993). Sk: 9878/2: Báta „Gyűrűsalj” J4 (K: 1995). 9879/1: Baja „Megyehatári-rét” J4 (Kevey in Kevey et al. 2006: 219; Kevey in Kevey et al. 2010: 223). BSzs: 7901/1: Nagyar „Tisza-ártér” J4 (KeveY \& BARNA 2016: 90). Tivadar „Dorongó” J4 (KeveY \& BARNA 2016: 90).

Dichostylis micheliana (L.) Nees - Sz: 8171/3: Ásványráró „Halrekesztő” J3 (KEVEY 2008: 18/3. táblázat).

Eleocharis acicularis (L.) Roem. et Schult. - Sz: 8171/1: Lipót „Örök-sziget” J3 (KeVEY 2008: 18/3. táblázat). 8171/3: Ásványráró „Halrekesztő” J3 (KeveY 2008: 18/3. táblázat), „Árva-sziget” J3 (KeVEY 2008: 18/3. táblázat), „Senki-sziget” J3 (Kevey 2008: 18/3. táblázat), „Laci-sziget” J3 (Kevey 2008: 18/3. táblázat).

Eriophorum angustifolium Honck. - Sz: 8171/3: Ásványráró „Kucsérok”! J1a (ALEXAY in KeVEY \& ALEXAY 1992: 1990).

Erythronium dens-canis L. - Az Atlas Florae Hungariae térképén (BARTHA et al. 2015: 288) több helyen félig befeketített körrel jelzik a növény lelőhelyeit. Részemről valamennyi lelőhelyét fekete koronggal jelölném, ugyanis legtöbb hazai lelőhelyét ismerem, s mindenütt életerős populációkban fordul elő. Kivételt képez a Doba alatti „Somló”, ahol magam mellett több botanikus is hiába kereste. BDs: 9972/3: Nemeske-Görösgal „Meggyes”! J6 (NAGY G. in KevEY \& HoRvÁT A. O. 2000: 56). DZ: 9466/3: Lispeszentadorján „Rákos-erdő”! K2, K5 (Lelkes ined.: 2006). Itt ma is megvan, ezért a térképen fekete koronggal jelölendő! 9566/2: Becsehely „Aligvári-hegy”! K2 (Lelkes ined.: 2006). BS: 9571/1: Nagybajom „Közép-Kak: a Pirosházi-legelő melletti erdőben” J5, K1a (KEvEY et PINTÉR A. in KEVEY 1990: 89), „Felső-Kak” J5, K1a, K5 (Kevey ined.: 1993). E két helyen ma is megvan, ezért a térképen fekete koronggal jelölendő! 9571/3: Nagybajom „Alsó-Kak” K1a (NovACSEK in KEVEY 1990: 89). 9771/3: Mike „a Petes-malomnál a Vidrapark mellett” S1 (Nagy T. ined.: 2001). Zs: 9772/1: Szenna „Denna-erdő” (IsÉPY in KeveY 1990: 90). 9772/3: Hedrehely „a Bordás-rét mellett” S1 (UhERKOvich Á. in Kevey 1990: 90). Itt ma is él, ezért a térképen fekete koronggal jelölendő! 9772/4: Bőszénfa-Szenttamáspuszta „Fácános”! 
K1a, K2 (NovaCSEK in Kevey 1990: 89), „Kopasz-domb” K2 (Novacsek in Kevey 1990: 89). E helyeken ma is előfordul, ezért a térképen fekete koronggal jelölendő! 9872/1: Patosfa „a falutól É-ra levő Vörösfaierdőben" (JuHÁsz M. in KEvEY 1990: 89). Itt ma is él, ezért a térképen fekete koronggal jelölendő! 9873/3: Almamellék (LÉHMANN in HoRvÁT A. 0. 1976: 27) „Szentegyedpuszta: Szentgáli-hegy” K2 (LÉHMANN in KEVEY 1990: 90). E helyen ma is él, ezért a térképen fekete koronggal jelölendő! Szd: Az első közlés Szekszárd néven történt (JÁvorKA \& Soó 1951: 855). Az adat Éhik Gyula zoológustól származik, aki a „Sötét-völgy”-ben látta a növényt, majd Jávorka Sándornak jelentette. Jávorka cédulakatalógusán mindez ma is megtalálható a Természettudományi Múzeum Növénytárában (Jávorka \& Csapody szoba). Az előfordulást a közelmúltban Zörényi János erősítette meg. Az ide vonatkozó enumerációs adatok így az alábbiak: 9677/4: Szekszárd (JÁvORKA \& Soó 1951: 855) „Sötét-völgy” (ÉHIK in KEVEY 1990: 90), „Sötétvölgy: a Haramia-forrás közelében”! K5 (ZÖRÉNYI in KEvEY \& HoRVÁT A. O. 2000: 56). Bü: 7890/3: Miskolc „Lyukó-völgy” (LESS in SiMON 1992: 660; VojTKó 2001: 274). Információim szerint itt ma is él. B: 8870/1: Doba „Somló” (SZABó J. in RÉDL 1942: 55). Ezt a régi előfordulást azóta többen is keresték (én is!), de senki sem találta meg újra. A térképen ezért a kihalt lelőhelyeket jelző kereszttel kell feltüntetni.

Fritillaria meleagris L. - BS: 0070/2: Barcs „Netecs-erdo”. Mintegy 10 tő! (Pintér A. ined.: 1991). DZ: 9465/1: Kerkateskánd „Berek-erdő” J6 (K: 2010), „Nagyszigeti-erdő” J6 (K: 2011).

Gagea lutea (L.) Ker Gawl. - Sz: 8270/2: Kimle „Malom-sziget” J6 (K: 1980). 8271/1: Mecsér „Szigeterdő” J6 (K: 1988). Hédervár „Zsejkei-erdő” J6 (K: 1982). 8272/3: Vének „Somos-erdő” J6 (K: 1987). 8272/4: Vének „Somos-erdő” J6 (K: 1987). R: 8468/1: Kapuvár „Rába-erdő” J6, K1a (K: 2005). 8668/1: Uraiújfalu „Kőréti-erdő” J6, K1a (K: 2014). 8668/2: Kenyeri „Nasici-erdő” K1a (K: 2004). VRv: 8867/3: Rum „Rumi-erdő” J6, K1a (KEVEY 2015e: 226). Zsennye „Zsennyei-erdő” J6 (K: 2016). Mm: 8770/1: Dáka „Tilos-erdő” J5, K1a (K: 2010). 8869/2: Kiscsősz „Nagy-erdő” K1a (K: 2009). 8869/4: Apácatorna „Galsai-erdő” J5, J6, K1a (K: 2013). Karakószörcsök „Felső-erdő” K1a (K: 2013). Tüskevár „Tüskevári-erdő” J6, K1a (K: 1991). 8870/1: Doba „Felső-erdő” K1a (K: 2010). 8969/1: Nemeskeresztúr „Karakói-erdő” K1a (K: 2013). 8970/1: Somlóvásárhely „Lovas-erdő” J6, K1a (K: 2013). Kv: 9465/1: Kerkateskánd „Berek-erdő” J6 (K: 2010), „Nagyszigeti-erdő” J6 (K: 2011). 9465/2: Iklódbördöce „Cserta-erdő” J6, K1a (K: 2009), „Kerka-erdő” J6, K1a (K: 2011), „Csertatorkolat” J6, K1a (K: 2011). Mv: 9465/3: Tornyiszentmiklós „Mura-erdő” K1a, K5 (KeveY in KeveY \& KovÁcs J. A. 2010: 212). Kerkaszentkirály „Szentkirályi-erdő” K1a (KeveY in Kevey \& KovÁcs J. A. 2010: 212). SDs: 9869/3: Bélavár „Bereki-erdo”” J6, K1a (KEVEY 2007a: 91). 9969/4: Babócsa „Dékány” J6, K1a (Kevey 2007a: 91), „Mérus-erdő” J6, K1a (Kevey 2007a: 91). Bolhó „Damacsin” J6, K1a (KeveY 2007a: 91). Bk: 7697/4: Ricse „Sása-szög” J6, K1a (K: 2008), „Lakonyai-erdő” J6, K1a (K: 2008). 7698/4: Zemplénagárd „a rév melletti erdőben” J6, K1a (K: 2008). BSzs: 7899/2: VásárosnaményUgornya „Bagiszeg-erdő” J6 (K: 1978). 7899/4: Vásárosnamény-Ugornya „Bagiszeg-erdő” J6, K1a (K: 1978). 7903/1: Magosliget „Cserköz-erdő” K1a (K: 2009). Köv: 9392/2: Gerla „Pósteleki-erdő” J6 (K: 1999). 9394/2: Gyula „Mályvádi-erdő” J6, K1a (K: 1998). Zm: 8577/3: Vértesboglár „Som-gödör” K1a (Kevey \& Simon Gy. ined.: 2009). 8676/2: Csákvár „Kastély-park” J6, K1a (K: 2011). Mf: 8678/4: Martonvásár „Gábormajori-erdő” J6 (K: 1997). 8877/4: Seregélyes „Kastély-park” J6 (K: 1997). 8879/3: Adony „Park-erdő” J6 (K: 1997). 8976/4: Soponya-Nagyláng „Kastély-park” J6, K1a (K: 1981). 8977/4: Sárosd „Kastély-park” J6, K1a (K: 1997). 9176/2: Dég „Őztelek” J6 (K: 1977), „Kastély-park” J5, J6, K1a (K: 1980). 9277/4: Vajta „Park-erdő” J6, K1a (KeveY in Kevey \& LendvaI: 2015: 23). 9378/1: Vajta "Nagy-erdő” K1a (KeVEY in KeVEY \& LendvaI: 2015: 23). Cssz: 8779/2: Szigetújfalu „Újfalusi-erdő” J6 (K: 1978). 8779/3: Szigetújfalu „Újfalusi-erdő” J6 (K: 1987). 8879/1: Ráckeve „Silling-erdő” J6 (K: 1988). 8879/3: Ráckeve „Besnyő” J6 (K: 1988). 8979/1: Makád „Rókás” J6 (K: 1989). Sk: 9679/4: Sükösd „Karaszi-erdő” J6 (KeVEY \& TóTH I. 2000: 139). 9779/1: Érsekcsanád „Veránka” J6 (Kevey \& TóTH I. 2000: 139). Msz: 0079/3: Hercegszántó-Karapancsa „Sziget-erdő” J6, K1a (Kevey \& Tóth I. 2000: 139). Sh: 8364/2: Ágfalva „Hidegvíz-völgy” J5, K1a (K: 1981). Bds: 8365/2: Sopron „Kő-hegy” K2 (K: 1979). A: 8665/4: Gencsapáti „Aponyi-park” K1a (K: 1998). 8667/3: Szeleste „Arborétum” J6, K1a (K: 1998). Khg: 9269/2: Balatongyörök „Kígyós-völgy” K2, K5, LY2 (K: 1986). 9270/1: Balatonederics „Cseres-ágya” K2 (K: 1982). 9169/1: Rezi „Hosszú-hegy” K5, LY1, LY2, LY4 (K: 1984). 9169/3: Cserszegtomaj „Csókakő” K2, LY1, LY2 (K: 2000). 9169/4: Vállus "Csetényi-erdő" K2, K5, LY1, LY2 (K: 1987). Ba: 8572/2: Gic „Gerencséri-erdő” J5 (KEvEY 2015b: 62). 8672/2: Bakonyszentlászló „Pagonyi-erdő” J5 (Kevey 2015b: 62). 8870/1: Doba „Somló” LY2, LY4 (K: 1989). 8871/3: Devecser „Beréndi-erdo”” J6, K1a (K: 1992). B: 8671/4: Ugod „Durrogós” K2, K5 (K: 1996), „Közép-hegy” K2 (K: 1996). 8773/2: Bakonynána „Római-fürdő” LY1 (K: 1995). ÉZ: 9168/2: Vindornyaszőlős „Alsó-erdő” K1a (K: 1993). 9267/4: Zalaszentmihály „Sinkei-erdő” J6 (K: 2014). DZ: 
9367/1: Söjtör „Fúró-hegy” K2, LY1 (K: 1985). 9465/2: Tormafölde „Csokmai-erdő” K2, K5 (K: 2012). 9465/4: Tormafölde „Centrale” J5, K2, K5 (K: 2012). 9466/1: Lasztonya „Cigány-árok” K5, LY1 (KeVEY 2008: 44/5. táblázat). Lispeszentadorján „Diós-völgy” K5, LY1 (KeveY 2008: 44/5. táblázat). 9466/3: Kiscsehi „Pityer-domb” K2, K5 (K: 2009). 9467/1: Bucsuta „Börzöncei-hegy” K1a, K2, K5 (K: 2009). 9468/1: Újudvar „Csibiti-völgy” K2, K5, LY1 (K: 2006). 9468/2: Zalakaros „Kanica-erdő” K2, K5 (K: 2006). 9468/4: Zalakaros „Szőlő-hegy” K2, K5, LY1 (K: 1991). 9566/1: Kistolmács „Fintafai-erdő” K2, K5 (K: 2009). Zajk-Józsefhegy „Béci-patak melletti erdőben” K2, K5 (K: 2009). 9568/2: Miháld „Sajcierdő” J5 (K: 1986). 9568/4: Nagyrécse „Virág-hegy” K2, K5 (K: 1978). Mh: 9570/3: Szenyér „Sáricsatorna” J5 (K: 2001). BS: 9469/3: Szőkedencs „Csörgető” J6 (K: 1999). Zalakomár-Ormándpuszta „Csöngő-kút” J5, J6 (K: 1989). 9470/4: Marcali „Kis-Gyóta” J6, K1a (K: 1991), „Nagy-Gyóta” J6, K1a (Kevey 2013a: 29). 9471/1: Csömend „Koszód” J5, J6 (K: 1990). 9471/3: Libickozma „Kopári-erdő” K1a (KeveY 2013a: 29). 9569/1: Somogysimonyi „Gödörberki-erdő” J5, J6 (K: 1998). Galambok „Vincédi-erdő” J6, K1a (K: 2014). 9570/4: Böhönye „Tranglus-erdő” J5, K1a (Kevey 2013a: 29). 9571/1: Mesztegnyő „Felső-Kak” J5, K1a, K5 (Kevey 2013a: 29). 9571/3: Nagybajom „Felső-Csikotaierdő” J5, K1a, K5 (KeveY 2013a: 29). 9769/2: Somogyszob „Kővölgyi-erdő” J5, K1a, K5 (Kevey 2013a: 29). 9769/4: Szenta „Döbrögi-erdő” K1a (Kevey 2013a: 29). 9771/1: Nagykorpád „Mórici-erdő” J5, K1a (KeveY 2013a: 29). 9771/3: Mike „Patkány-domb” J5, K1a (K: 1996). KS: 9471/2: Somogyvár „Brézai-erdő” K2 (K: 1997). 9472/1: Somogyvár „Télizöld” J5, K2 (K: 1998). 9473/1: Kisbárapáti „Lucai-erdő” K2, K5 (K: 1993). Zs: 9674/3: Szabadi „Szörnyű-gödör” J5, K2 (K: 2012). Nagyberki „Vadas-kert” J5, K2 (K: 2013). Kercseliget „Szilvási-erdő” K2 (K: 2012). Mcs: 9776/2: Váralja „Váraljai-völgy” K2, K5 (K: 2011). 9874/3: Hetvehely „Sás-völgy” J5, K1a (K: 1979). Bakonya „Pajtnervölgy” K2, K5 (Kevey 2015d: 24). Kővágótöttös „Sás-völgy” K1a, K2, K5 (K: 1979). Bakonya „Sásvölgy” K1a, K2, K5 (K: 1990). 9875/1: Magyarszék „Szentimre-erdo”” J5, K2, K5 (Kevey \& BARANYI 2002: 15). Vlhg: 0075/4: Kistótfalu „Csicsó-hegy” K2, K5 (KeVEY 1987a: 1. táblázat). 0175/2: Bisse „Remete” K2, K5, LY1 (Kevey 1987a: 1. táblázat), „Pécsi-lapis” J6, K1a, K2, K5 (Kevey 1987a: 1. táblázat), „Poszhagymás” K1a, K2, K5 (KeveY 1987a: 1. táblázat). Kistótfalu „Átai-hegy” K2, K5, LY1 (KeveY 1985b: 26). V: 9575/4: Kurd „Szentkúti-erdő” J6 (K: 2013). 9676/1: Lengyel „Fürdő-erdő” K2, K5 (Kevey \& Horvát A. O. ined.: 1977). Bd: 0075/2: Egerág „Halastói-erdő” K1a (K: 2013). 0075/3: Garé „Konisa-erdő” K1a (K: 1994). 0076/3: Újpetre „Palkonyai-erdő” K1a (K: 2006). 9975/3: Kökény „Malom-völgy” K1a (K: 1994). 9975/4: Pécs-Nagyárpád „Pécsudvardi-erdő” K1a (K: 1977).

Gagea minima (L.) Ker Gawl. - BSzs: 7700/1: Tiszakerecseny „Lónyai-erdő” J6, K1a (Kevey \& Lesku ined.: 2003). B: 8774/4: Várpalota „Bér-hegy” LY4 (K: 2018). 8873/1: Lókút „Papod” LY4 (K: 2016). Vlhg: 0176/2: Nagyharsány „Szársomlyó” LY2, LY4 (K: 1987).

Gagea spathacea (Hayne) Salisb. - BSzs: 7700/1: Tiszakerecseny „Lónyai-erdő” J6, K1a (K: 2003). 7701/3: Beregdaróc „Dédai-erdő” J6, K1a (K: 2003), „Közös-erdő” J6, K1a (K: 2009). 7801/1: Beregdaróc „Csere-erdő” K1a (K: 2009). 7901/2: Kömörő „Páskom” J6, K1a (K: 2003). 7901/3: Mánd „Mándi-erdő” J6 (K: 2003). 7903/1: Magosliget „Cserköz-erdő” K1a (K: 2003). Kv: 9365/1: Bárszentmihályfa „Bárhelyi-erdő” J6, K1a (K: 2001). Kerkabarabás „Medesi-erdő” J6, K1a (K: 2011). 9465/1: Kerkateskánd „Nagyszigeti-erdő” J6 (K: 2011). 9465/2: Iklódbördöce „Kerka-erdő” J6, K1a (K: 2011), „Cserta torkolata” J6, K1a (K: 2011), „Cserta-erdo” J6, K1a (K: 2010).

Galanthus nivalis L. - Sz: 8170/2: Kisbodak „Pálfi-erdő” J6 (K: 1985). Ghv: 8373/1: Bőny „Bőnyi-erdő” J6, K1a (Kevey \& Alexay ined.: 2005). Mm: 8770/1: Dáka „Tilos-erdő” J5, K1a (K: 2010). 8869/4: Apácatorna „Galsai-erdő” J5, J6, K1a (K: 2013). VRv: 8867/3: Rum „Rumi-erdő” J6, K1a (KEVEY 2015e: 227). Tv: 8781/1: Ócsa „Nagy-erdő” J6, K1a (K: 2015). Cssz: 8680/3: Szigethalom „Tököli-erdő” J6 (K: 1993). 8779/3: Szigetújfalu „Újfalusi-erdő” J6 (K: 1978). 8779/4: Szigetújfalu „Újfalusi-erdő” J6 (K: 1978). 8879/1: Ráckeve „Silling-erdő” J6 (K: 1978). 8879/3: Lórév „a rév és Makád közötti erdőben” J6 (K: 1978). Ráckeve „Besnyő” J6 (K: 1988). 8979/1: Makád „Rókás” J6 (K: 1983). 8979/4: Makád „Sasréti-erdő” J6 (K: 1990). Sk: 9679/1: Fajsz „Karaszi-erdő”! J6 (TóTH I. in KeveY \& TóTH I. 2000: 140). 9679/3: Ő́csény „Kis-Gemenc”! J6 (TóTH I. in Kevey \& TóTH I. 2000: 140), „Keselyűs”! J6 (TóTH I. in KeveY \& TóTH I. 2000: 140). 9779/1: Érsekcsanád „Veránka”! J4, J6 (Tóth I. in KeveY \& TóTH I. 2000: 140). 9879/1: Baja „Közép-Pörböly”! J6 (Tóth I. in Kevey \& TóTH I. 2000: 140). Msz: 0078/2: Homorúd „Harci-zátony”! J4 (EGERSZEGI ex verb.: 2016; KeveY 2017b: E1. táblázat). Kölked „Szúnyog-sziget”! J4, J6 (Deme ex verb.: 2008). 9978/2: Dunafalva „Csele-erdő"! J4 (Egerszegi ex verb.: 2016; KeVEY 2017b: E1. táblázat). Mf: 8678/4: Martonvásár „Gábormajori-erdo”” J6 (K: 1997), „Kastély-park” J6, K1a (KeveY et al. 2016: Table S2). 8976/4: Soponya-Nagyláng „Fácános-erdő” J6 (K: 1977), „Kastély-park” J6, K1a (K: 1982). 8977/2: Sárosd „Park-erdő” J6 (K: 1998). 8979/1: Adony „Szentmihályi-erdo” J6 
(Kevey \& Lendvai ined.: 2007). 9076/2: Káloz „Belmajor” J6 (K: 1984). 9176/2: Dég „Ördög-domb” J6, K1a (K: 1979). BDs: 0073/1: Sumony „Sumonyi-erdő” K1a (Kevey 2007b: 48). 9973/3: Botykapeterd „Botykai-erdő” K1a (KeveY 2007b: 48). Dk: 0276/2: Beremend „Beremendi-erdo” J6, K1a (K: 2007). Sh: 8365/2: Sopron „Lővér-erdő" K2 (K: 1997). A: 8566/2: Sopronhorpács „Kastély-park” J6 (K: 1998). 8665/4: Gencsapáti „Aponyi-park” K1a (K: 1998). 8667/3: Szeleste „Arborétum” K1a (K: 1998). Khg: 9169/4: Vállus „Szentmiklós-völgy” K5, LY1 (K: 1985). 9269/2: Balatongyörök „Kígyósvölgy” K5, LY2 (K: 1986). Ba: 8672/2: Bakonyszentlászló „Pagonyi-erdő” J5 (KeveY 2015b: 63). B: 8771/2: Bakonyjákó-Iharkút „Sármás” J5, K2, K5 (K: 2015). 8774/1: Tés „Tési-erdő” K2, K5 (K: 2017). Vehg: 8772/2: Lovasberény „Templom-hegy és Antónia-hegy között” K2 (KEVEY in KeVEY et al. 2014: 233). Kv: 9465/1: Kerkateskánd „Nagyszigeti-erdő” J6 (K: 2011). 9465/2: Iklódbördöce „Csertatorkolat” J6, K1a (K: 2011). ÉZ: 9168/1: Gyűrűs „Kígyós” K2, K5 (K: 1976). DZ: 9367/1: Söjtör „Fúróhegy” K5, LY1 (K: 1985). 9467/3: Homokkomárom „Aligvári-hegy” K2, K5 (K: 2013). 9566/1: Kistolmács „Fintafai-erdő” K2, K5 (K: 2009). 9568/2: Miháld „Sajci-erdő” J5 (K: 1986). 9568/4: Nagyrécse „Virág-hegy” K2, K5 (K: 1978). 9667/4: Surd „Bükkfakúti-erdő” K2 (K: 1987). 9668/1: Liszó „Medvés” K2, K5 (K: 1988). 9668/2: Iharosberény „Szentpáli-erdo” K2, K5 (K: 1988). BS: 9470/4: Marcali „Kis-Gyóta” J6, K1a (Kevey 2013a: 28), „Nagy-Gyóta” J6, K1a (Kevey 2013a: 28). 9471/3: Libickozma „Kopári-erdő” K1a (KeveY 2013a: 28). 9571/3: Nagybajom „Középső-Kak: a Pirosházi-legelő közelében” J5, K1a (KeveY 2013a: 28). 9769/3: Szenta „Kiskunovica” J5, K1a (K: 1982). 9769/4: Szenta „Döbrögi-erdő” K1a (KeVEY 2013a: 28). 9771/1: Nagykorpád „Mórici-erdő” J5, K1a (Kevey 2013a: 28). 9870/1: Rinyaszentkirály „Polai-erdő” J5, J6, K1a (K: 1989), „Ág-erdő” J5, J6, K1a (K: 1997). Zs: 9872/1: Vásárosbéc „Öreg-hegy” K2 (Horvát A. O. \& Kevey ined.: 1975). V: 9775/1: Kisvaszar „Hosszú-erdő” J6, K2, K5 (K: 2008). 9775/3: Kisvaszar „Bikági-völgy” J5, J6, K1a, K2, K5 (K: 1978). Mcs: 9874/3: Hetvehely „Sás-völgy” J5, K1a, K2 (K: 1979). Bükkösd „Pajtner-völgy” K2, K5 (KeveY 2015d: 24). Vlhg: 0075/4: Kistótfalu „Csicsó-hegy” K2, K5 (Kevey 2016: 36). 0076/3: Vokány „Trinitás-erdő” J6, K1a, K2 (Kevey 2016: 36). Bd: 0075/3: Turony „Sziget” K2 (K: 2010). 9975/3: Kökény „Malom-völgy” K1a (K: 1994). Gd: 9777/4: Bátaapáti „Nagy-Mórágyi-völgy” K2, K5, LY1 (K: 2004). 9877/1: Geresdlak „Kisgeresdi-erdo”" K1a, K2 (K: 2004). 9877/3: Geresdlak „Kisgeresdi-erdő” K1a, K2 (K: 2004). Szd: 9677/4: Szekszárd „Fazekas-völgy” K2, K5 (K: 1990).

Hemerocallis lilio-asphodelus L. - BS: 9569/1: Somogysimonyi „Gödörberki-erdő” J6 (K: 1998). 9570/4: Böhönye-Dávodpuszta „Tranglus-erdő” K1a (KEVEY 2013a: 34). 9571/3: Nagybajom „Cífratanya és a Dávodi-tó között” J5 (K: 1991). 9771/3: Mike „Felső-erdő” K1a (K: 1996). A flóraatlasz (BARTHA \& KIRÁLY 2015) 1950 előtti adatként jelzi. Előfordulása most megerősítést nyert, ezért a térképen fekete koronggal jelölendő!

Maianthemum bifolium (L.) F.W. Schmidt - Bk: 7698/3: Révleányvár „Bodzás” K1a (K: 2008). BSzs: 7701/3: Beregdaróc „Közös-erdő” K1a (K: 2009). 7801/1: Beregdaróc „Csere-erdő” K1a (K: 2009). 7901/2: Kömörő „Páskom” K1a (K: 2009). Ny: 7998/4: Baktalórántháza „Baktai-erdő” K1a (KEVEY in KEVEY et al. 2017a: E1. Táblázat). 8199/4: Terem „Nagyfenék” J6, K1a (KeveY in KeveY et al. 2017b: 204). DTk: 8984/1: Nagykőrös „Nagy-erdő" (Boros 1935: 7; DEgEN in Hargitai 1937: 27). Azóta a növény előfordulásáról nincs információ! Tv: 8781/1: Ócsa „Mádencia felé” Láperdőben! (BoRos 1936: 88). JÁRAI-KOMLÓDI (1958) már nem említi. Előfordulása azóta ismeretlen! VRv: 8867/2: Ikervár „Gógány” K1a (KeveY 2015e: 227). 8965/3: Kemestaródfa „Bagólé-erdő” K1a (KEVEY 2015e: 227). Mv: 9667/1: Murakeresztúr „Gyurgyánc” K1a (KeveY in KeveY \& KovÁcs J. A. 2010: 212). SDs: 9869/1: Somogyudvarhely „Vecsenye” K1a (Kevey 2007a: 93). BDs: 0072/2: Bürüs „Keselőc” K1a, K5 (KeveY 1998: 19). Kh: 8665/1: Kőszeg „Szabó-hegy” K2 (K: 1989). Khg: 9069/4: Zalaszántó „Kovácsi-hegy” K2, K5 (K: 1988). 9169/1: Rezi „Hosszú-völgy” K5, LY1 (K: 1984). 9169/4: Vállus „Barbacsi-erdo”” K2, K5 (K: 1986). Ba: 8672/1: Pápateszér „Görgő-ér” K1a (KeVEy 2014: 61). 8870/2: Noszlop „Becsei-erdő” K1a (K: 2003). 8871/3: Devecser „Széki-erdő” K1a (K: 2003). B: 8771/4: Farkasgyepű „Felső-erdő” K2, K5 (K: 2017). 8873/1: Hárskút „Esztergály-völgy” K5 (K: 1998). ÉZ: 9167/1: Zalaszentiván „Kisfaludihegy” K2, K5 (K: 1982). 9168/1: Gyűrűs „Kígyós” K2, K5 (K: 1993). 9168/3: Nagykapornak „Tilajierdő” K2, K5 (K: 1992). DZ: 9465/2: Tormafölde „Csokmai-erdő” K2, K5 (K: 2012). 9566/2: Valkonya „a Valkonyai-patak melletti erdőben” K2, K5 (K: 2008). 9568/3: Bagola „Bagolai-erdő” K2 (K: 2015). 9667/3: Murakeresztúr „Beleznai-erdő: Zrínyi-forrás” K1a (Kevey \& Toldi ined.: 1997). BS: 9470/4: Marcali „Nagy-Gyóta” J6, K1a (K: 1994). 9471/3: Libickozma „Kopári-erdő” K1a (KeveY 2013a: 28). 9570/4: Böhönye-Dávodpuszta „Halastói-erdő” K1a (K: 1993). 9571/1: Mesztegnyő „Felső-Kak” J5, K1a, K5 (Kevey 2013a: 28). 9571/3: Nagybajom „Közép-Kak: a Pirosházi legelő melletti erdőben” J5, K1a (Kevey 2013a: 28), Lencsenpuszta és Szili-Bükk között” K1a (KeVEY 2013a: 28), „Felső-Csikotai- 
erdő” J5, K1a, K5 (Kevey 2013a: 28). 9669/3: Szenta „Baláta-tó” J6, K1a (Borhidi \& Kevey ined.: 1990). 9669/4: Somogyszob „Bükki-malom” J6, K1a, K5 (K: 1975), „Kővölgyi-erdő” J6, K1a, K5 (Kevey $2013 a$ : 28), „Rinya-erdő” J6, K1a (Kevey 2013a: 28), „Szénégető” J6, K1a (Kevey 2013a: 28). 9769/1: Szenta „Kiskunovica” J5, K1a (K: 1982). 9770/3: Nagyatád „Ámor-erdő” J6, K1a (K: 1983). 9771/1: Nagykorpád „Mórici-erdő” J6, K1a (Kevey 2013a: 28). 9771/3: Mike „Patkány-domb” J6, K1a (K: 1996).

Melica uniflora L. - Mf: 8678/4: Martonvásár „Kastély-park” J6 (K: 1980). Tv: 8781/1: Ócsa „Nagyerdő” J5 (K: 2018). Egyetlen helyen néhány kicsiny populáció!

Orchis purpurea Huds. - J: 8686/4: Szászberek „Berenta-erdő” J6 (KEVEY et URBÁN ined.: 2018).

Ornithoghalum sphaerocarpum A. Kern. - R: 8569/2: Rábaszentandrás „Szentandrási-erdő” J5, J6 (K: 2000). Mf: 9378/1: Bikács-Kistápé „Csorda-mező” K1a, L5 (Kevey in Kevey \& Lendvai 2015: 26). 9378/2: Németkér „Látó-hegy” K1a, L5 (Kevey in Kevey \& Lendval 2015: 26). Kv: 9365/1: Kerkabarabás „Medesi-erdő" K1a (K: 2011). 9365/3: Lenti „Vár-erdő” K1a (K: 2011). Mv: 9667/1: Murakeresztúr "Gyurgyánc” J6 (KeveY in Kevey \& KovÁcs 2011: 226). Khg: 9069/3: Zalaszántó „Kovácsi-hegy” K2, LY4 (K: 2000). 9069/4: Bazsi „Bazsi-erdő” K1a (K: 2007). Zalaszántó „Tátika” K2, LY2, LY4 (K: 2007). Lesenceistvánd-Uzsa „Hubertusz” K1a, LY2 (K: 1993). 9169/2: Zalaszántó „Várberek” J6, K1a (K: 1988). Lesenceistvánd „Kű-orra” K2, LY2, LY4 (K: 2014). 9169/4: Rezi „Fagyoskereszt” K2, K5 (K: 1987). Vállus „Köves-tető” K2 (K: 1985). 9170/3: Nemesvita „Sárkány-erdo”” K2, K5 (K: 1986). 9270/1: Balatonederics „Cseres-ágya” K2 (K: 1986). Bf: 9270/2: Badacsonytomaj „a Badacsonyi-hegy keleti lábánál” K2 (Kevey et Vöröss L. Zs. ined.: 1976). Ba: 8770/4: Kúp „Kúpi-erdő” K1a (K: 1989). 8771/1: Pápakovácsi „Attyai-erdő” K1a (K: 2003). 8871/3: Devecser „Beréndi-erdő” J6, K1a (K: 1992), „Széki-erdő” J6, K1a (K: 2002). B: 8773/4: Olaszfalu-Alsópere „Puszta-berek” J5 (K: 1996). 9073/3: Lesenceistvánd-Uzsa „Kisbakonyi-erdő” K1a (K: 2001). ÉZ: 9168/2: Vindornyaszőlős „Alsó-erdő” K1a (K: 1993). 9267/3: Pölöske „Sohollár” K1a (K: 2014). DZ: 9467/3: EszteregnyeObornak „Márki-erdő” K2, K5 (K: 1986). 9467/4: Hosszúvölgy „Zsigárdi-erdő” J6, K1a (K: 2015). 9667/3: Belezna „Sándor-hegy” J6, K1a (K: 2016). 9668/2: Iharosberény „Szentpáli-erdő” K2, K5 (K: 1987). Zd: 9667/3: Őrtilos „Vasút-oldal: Dűlt-hegy” K2, L2a (KeveY 2013d: 57). 9767/2: Zákány „Vasút-oldal: Hagymás-völgy” K2 (KeveY 2013d: 57). BS: 9570/2: Mesztegnyő „Dávodi-tó és Soponyai-tó között” K1a (K: 1985). 9769/4: Szenta „Döbrögi-erdő” K1a (KEVEY 2013a: 35). 9771/3: Mike „Patkány-domb” J5, K1a (K: 1996). Mcs: 9876/1: Hosszúhetény-Kisújbánya „Mészégető” K2, LY2, LY4 (K: 1987). 9876/2: Pécsvárad „Csiger-tető” L1 (K: 2017). Bd: 0075/2: Egerág „Halastóierdő" K1a (K: 2013). 0075/3: Bosta „Nagy-erdő” K1a (K: 1994). Gd: 9877/2: Bátaapáti „Fenyves-tető” K2, L2a (K: 1990). Szd: 9778/1: Szálka „Rác-erdő” K1a K2 (K: 1990).

Polygonatum multiflorum (L.) All. - DTk: 9680/2: Hajós „Sasfészek” (K: 2018).

Potamogeton lucens L. - Sz: 8069/4: Mosonmagyaróvár „Parti-erdő” J2 (KeVEY \& AlEXAY 1996: 15).

Potamogeton natans L. - Sz: 8271/1: Dunaszeg „Holt-Duna” J1a (K: 1998).

Ruscus aculeatus L. - SDs: 9869/1: Somogyudvarhely „Vecsenye” J5 (BoRHIDI 1958b: 357). Vh: 8967/1: Kám „Jeli Arborétum: Hét-forrás” K2 (KEVEY 1981: 181). Valószínűleg ültetve! Khg: 9169/3: Rezi „Meleg-hegy” K2, K5, LY2, LY4 (K: 1984). Bf: 9170/4: Szigliget „Antal-hegy” K2 (K: 1986). Mf: 9478/1: Tengelic „Csapó kastély parkjában ültetve” K1a (K: 1986). Mh: 9770/1: Ötvöskónyi „Alsóbogáti-erdő” K1a (K: 1996). BS: 9571/1: Mesztegnyő „Felső-Kak” J5, K1a, K5 (JuHÁsz in KeveY et al. 1992b: 34). 9571/3: Nagybajom „Felső-Csikotai-erdő” J5, K1a, K5 (JuHÁsz in KeVEY et al. 1992b: 34), „Középső-Kak: a Pirosházi-legelő melletti erdőben" J5, K1a, K5 (KeVEY \& PINTÉR in KevEY et al. 1992b: 34). 9769/3: Szenta „Kiskunovica” J5, K1a (HoRvát A. O. \& KEVEY in KEVEY \& BARTHA 2010: 281). 9771/1: Nagykorpád „Mórici-erdő” J5, K1a (Kevey 1988b: 17). KS: 9272/4: Nagycsepely „Tengerde” (RozNER 2011: 13). 9273/3: Nagycsepely „Hosszú-Kopasz-hegy” K2 (Pintér A. ex verb.: 2003; RozNER 2011: 13). 9371/4: Kisberény „Kisberényi-erdő” (RozNER 2011: 13). 9372/2: Somogybabod „Galabár” (RozNER 2011: 13). 9372/3: Somogyvár „Gárdony” (RozNeR 2011: 13). Hács „Gárdony” (RozNer 2012: 13). 9472/1: Somogyvár-Vityapuszta „Télizöld” J5, K2 (KeVEY in KEVEY \& BARTHA 2010: 280; RozNER 2011: 13). Szd: 9778/1: Szálka „Rác-erdő” J5, K2 (KeVEY in KEVEY \& BARTHA 2010: 292).

Ruscus hypoglossum L. - Vh: 8967/1: Kám „Jeli: Hét-forrás” K2, K5 (K: 1989). Őshonossága vitatott! B: 8771/4: Farkasgyepű „Felső-erdő” K5 (K: 2017). DZ: 9468/1: Újudvar „Csibiti-völgy” K2, K5, LY1 (KeveY 2008: 44/7. táblázat). 9468/4: Zalakaros „Szőlő-hegy” K2, K5, LY1 (K: 1991). Zs: 9774/1: Baranyajenő „Kósa-gödör” K2, K5 (K: 1997).

Scilla drunensis Speta - VRv: 8867/2: Ikervár „Gógány” K1a (Kevey 2015e: 226). 8867/3: Rum „Rumierdő” J6, K1a (KEVEY 2015e: 226). 8967/1: Rum „Rumi-erdő” J6, K1a (KEVEY 2015e: 226). Kh: 8664/4: Bozsok „Kastély-park” K1a (Kevey \& Csapody I. ined.: 1985). Vh: 8868/3: Káld „Avas-erdő” K1a, K2 
(K: 1981). Kv: 9465/2: Iklódbördöce „Kerka-erdő” J6, K1a (K: 2011). SDs: 9768/4: BerzencePerdócmajor „Park-erdő” J6 (Kevey 2013b: 119). DZ: 9567/2: Hosszúvölgy „Zsigárdi-erdő” J6, K1a (K: 2015). 9568/2: Miháld „Sajci-erdő” J5 (K: 1986). 9568/3: Nagyrécse „Virág-hegy” K2, K6 (K: 1986). 8667/4: Surd „Bükkfakúti-erdő” K2 (K: 1987). Zd: 9767/2: Őrtilos „Szentmihály-hegy: Templomvölgy” K2, K5 (Kevey 2009: 224; Kevey 2013e: 242), „Vasút-oldal: Földvári-hegy” K2, K5 (KeVEy 2009: 224; Kevey 2013e: 242), „Vasút-oldal: Páfrányos” J5, K2, K5, LY1 (K: 1983), „Visszafolyó-patak” J2, J5 (Kevey \& Toldi 2013: 61). BS: 9471/1: Csömend „Koszód” J5, J6 (K: 1981). 9569/1: Somogysimonyi „Gödörberki-erdő” J5, J6 (K: 1998). Galambok „Vincédi-erdő” J5, J6 (K: 2014). 9571/1: Mesztegnyő „Felső-Kak” J5, K1a, K5 (Kevey \& KLUJBER in KeveY et al. 1998: 251). 9771/1: Nagykorpád „Móricierdő" J5, K1a (KeVEY 2013a: 30).

Scilla kladnii Schur - BSzs: 7701/3: Beregdaróc „Dédai-erdő” K1a (K: 2003), „Közös-erdő” K1a (K: 2009). 7801/4: Tarpa „Nagy-erdő” J6, K1a (K: 2003). 7903/1: Magosliget „Cserköz-erdő” K1a (K: 2003). 8002/2: Túrricse „Ricsei-erdő” J6, K1a (K: 2009).

Scilla vindobonensis Speta - Sz: 8170/2: Kisbodak „Alsó-sziget” J4 (K: 1991), „Pálfi-erdő” J4, J6 (K: 1985). 8171/1: Lipót „Új-sziget” J4 (K: 1991). 8171/2: Ásványráró „Sült-domb” J4 (Kevey 2008: 22/3. táblázat). 8171/3: Ásványráró „Madarász-sziget” J4 (K: 1991). 8270/2: Kimle-Novákpuszta „Malomsziget” J6 (K: 1980). H: 8269/3: Jánossomorja „Hanság-Nagy-erdo”” J6 (K: 2001). 8269/4: Jánossomorja-Hanságliget „Korona-erdő” J6 (K: 2001). Ghv: 8373/1: Bőny „Bőnyi-erdő” J6, K1a (K: 2005). Mm: 8770/1: Dáka „Tilos-erdő” K1a (K: 2010). Tv: 8781/1: Ócsa „Nagy-erdő: az erdészház közelében” J6 (K: 2015). 8781/4: Dabas „Cibaktanya közelében levő erdőben” J6 (Kevey \& Nagy I. ined.: 2015). J: 8586/3: Alattyán „Berki-erdő” J5 (Kevey et URBÁN ined.: 2018). Szsz: 8380/4: Szigetmonostor "a Horányi-rév alatti erdőben” J6 (Bőhm ex verb.: 2011). Cssz: 8679/4: Százhalombatta „Kacsás-sziget” J4 (K: 1998). 8680/1: Budapest „Háros-sziget” J4 (KEvEY \& Huszár 1999: 42). 8680/3: Szigethalom „Tököli-erdő” J6 (K: 1993). 8779/1: Szigetújfalu „Újfalusi-erdő” J6 (K: 1978). 8779/2: Tököl „Tököli-erdő” J6 (K. 1978). 8779/3: Ercsi „Sziget” J6 (K: 1997). 8780/1: Tököl „Tököli-erdő” J6 (K. 1978). 8879/1: Ráckeve „Silling-erdő” J6 (K: 1978). 8879/3: Ráckeve „Besnyő J6 (K: 1988). 8979/1: Lórév „Makádi-erdő” J6 (K: 1983). Makád „Rókás” J6 (K: 1978). 8979/4: Makád „Sasréti-erdő” J6 (K: 1990). Rácalmás „Kis-sziget” J4 (K: 1998). Sk: 9679/1: Fajsz „Karaszi-erdő” J6 (Tóth I. in Kevey \& Tóth I. 2000: 139). Sükösd „Karaszi-erdő” (Tóth I. in KeveY \& TótH I. 2000: 139). 9779/1: Érsekcsanád „Veránka” J6 (Boros in Kevey \& TóTH I. 2000: 139; TóTH I. in KeveY \& TótH I. 2000: 139). 9779/3: Baja „Kis-Rezét: a Holt-Duna partján” J4, J6 (Boros in KeveY \& TóTH I. 2000: 139; TóTH I. in Kevey \& Tóth I. 2000: 139). Msz: 0078/1: Mohács „Cigány-zátony” J4 (Kevey 2017b: E1. Táblázat). 0078/2: Kölked „Szúnyog-sziget” J4 (K: 2016), „Nagypartos” J4 (Kevey \& Gregorits ined.: 2016; KeVEY 2017b: E1. táblázat). Mohács „Harci-zátony” J4 (Kevey \& Egerszegi ined.: 2016; Kevey $2017 b$ : E1. Táblázat). 9978/2: Dunafalva "Csele-erdő” J4 (Kevey \& Egerszegi ined.: 2016; KEvEY 2017b: E1. táblázat). Mf: 8678/4: Martonvásár „Kastély-park” J6 (KEVEY 1985a: 157), „Gábormajori-erdő” J6 (K: 1997). 8879/3: Adony „Kastély-park” J6 (K: 1997). 8976/2: Aba-Felsőszentiván „Holdvilág-tavak” J6 (K: 1999). 8976/4: Soponya-Nagyláng „Kastély-park” J6, K1a (HANGAY 1889: 156; KeveY 1985a: 157), „Fácános-erdő” J6 (Kevey 1985a: 157). 9076/2: Káloz-Belmajor „Kastély-park” J6 (K: 1984). 9176/3: Lajoskomárom „Újmajor és Tüskéspuszta között” L5 (KEVEY \& LENDVAI in LENDVAI et al. 2014: 167). 9277/4: Vajta „Park-erdő” J6, K1a (Kevey in Kevey \& Lendvai 2015: 23). 9378/1: Bikács-Kistápé "Csorda-mező" K1a (Kevey \& Lendvai 2015: 23). 9378/2: Paks-Gyapa „Cseresznyés” K1a (Kevey \& LENDVAi 2015: 23). BDs: 0073/3: Sumony „Sumonyi-erdő” K1a (KEVEY 2007b: 49). HNs: 0177/2: Majs „Nagy-erdő” J6, K1a (K: 2001). Ba: 8672/1: Pápateszér „Görgő-ér” K1a (KEVEY 2015b: 62). B: 8772/1: Ugod „Hubertlak: Szalai-Séd” J5 (K: 1996). 8672/3: Ugod „Som-berek” K2, LY4 (K: 2015). Khg: 9069/3: Zalaszántó „Kovácsi-hegy” K2, K5 (K: 1988). 9069/4: Bazsi „Bazsi-erdő” K1a (K: 2007). ÉZ: 9168/1: Gyürűs „Kígyós” K2 (K: 1976). Kallosd „Kaponya” J5, J6 (K: 1976). 9168/2: Vindornyaszőlős „Alsóerdő” K1a (K: 1993). Zs: 9872/4: Csertő „Szőlő-hegy” K2 (K: 2015). V: 9575/4: Kurd „Szentkúti-erdő” J6 (K: 2013). 9774/4: Felsőegerszeg „Káptalan-erdő” K2 (K: 2014). KS: 9471/2: Somogyvár „Brézaierdő” K2 (K: 1997). 9575/2: Döbrököz „Hajagos-erdo” K1a (K: 1988). Th: 9376/2: Nagyszékely „Kalános-erdő” K1a (K: 2014). Mcs: 9874/3: Hetvehely „Sás-völgy” J5, K1a (K: 1978). 9874/4: Kővágótöttös „Sás-völgy” J6, K1a, K2 (K: 1978). 9875/2: Mánfa „Száraz-gödör” J6, K1a, K2, K5, LY2, LY4 (K: 1991). Vlhg: 0076/3: Vokány „Trinitás-erdő” J6, K1a (KEvEY 2016: 36). Bd: 9977/2: Székelyszabar „Szabari-erdő” K1a (K: 2010). Gd: 9777/3: Ófalu „Kalktal” K2 (K: 2006). Szd: 9677/4: Szekszárd „Sötét-völgy” J5, K1a (K: 1977). 9678/3: Szekszárd „Gurovica” K2 (K: 1988). 
Scirpus radicans Schkuhr - Sz: 8171/3: Ásványráró „Halrekesztő” J3 (KEVEY 2008: 18/3. táblázat). 8170/2: Lipót „Harmadik-erdő” J3 (K: 1992). 8171/1: Lipót „Örök-sziget” J3 (KeveY 2008: 18/3. táblázat). 8171/4: Ásványráró „Gyalap” J3 (K: 1992), „Nagy-sziget=Ercséd” J3 (KeVEY 2008: 18/3. táblázat).

Tamus communis L. - Mm: 8870/1: Doba „Felső-erdő” K1a (K: 2005). Mv: 9667/1: Murakeresztúr „Gyurgyánc” J6, K1a (KeveY in KeveY \& KovÁcs J. A. 2010: 214). SDs: 9869/1: Somogyudvarhely „Vecsenye” J6, K1a (KeveY 2007a: 94). Khg: 9069/4: Zalaszántó „Tátika” K1a, K2, K5, LY2, LY4 (K: 1979), „Farkas-hegy” K2, K5 (K: 1979). Bazsi „Bazsi-erdő” K1a (K: 2007). Sümegprága „Sarvaly” K1a (K: 2006). Lesenceistvánd-Uzsa „Istvándi-erdő” K1a (K: 2005). Bf: 9270/2: Badacsonytomaj „a Badacsonyi-hegy platóján” K2 (Kevey \& Vöröss L.Zs. ined.: 1976). B: 9070/3: Lesenceistvánd „Kisbakonyi-erdő” K1a (K: 2001). ÉZ: 9168/2: Vindornyaszőlős „Alsó-erdő” K1a (K: 1993). DZ: 9367/1: Söjtör „Fúró-hegy” K2, K5, LY1 (K: 1985). 9468/1: Nagybakónak „Tukora” LY1 (KeveY 2008: 44/7. táblázat). Újudvar „Csibiti-völgy” K2, K5, LY1 (KeVEY 2008: 44/7. táblázat). BS: 9470/4: Marcali „Kis-Gyóta” J6, K1a (Kevey 2013a: 32) „Nagy-Gyóta” J6, K1a, K5 (KeVEY 2013a: 32). 9569/1: Galambok „Vincédi-erdő" (K: 2014). 9570/4: Böhönye-Dávodpuszta „Tranglus-erdő” K1a (NNagy-Gyóta” J6, K1a (Kevey 2013a: 32). 9571/1: Mesztegnyő „Felső-Kak” J5, K1a, K5 („Nagy-Gyóta” J6, K1a (Kevey 2013a: 32). 9571/3: Nagybajom „Bükk” K1a, K5 (K: 1992). 9771/1: Nagykorpád „Mórici-erdő” J5, K1a („Nagy-Gyóta” J6, K1a (Kevey 2013a: 32). 9771/3: Mike „Patkány-domb” J5, K1a (K: 1995). 9870/1: Rinyaszentkirály „Polai-erdő” J5, J6, K1a („Nagy-Gyóta” J6, K1a (KeveY 2013a: 32). KS: 9471/2: Somogyvár „Brézai-erdő” K2 (K: 1997). V: 9676/1: Lengyel „Fürdő-erdő” K2, K5 (Horvát A.O. \& Kevey ined.: 1977), „Papdi-erdő” K2, K5 (Horvát A.O. \& Kevey ined.: 1977). 9775/1: Kisvaszar „Bikági-erdő” J5, J6, K1a, K5 (K: 1978), „Hosszú-erdő” J6, K1a (K: 2004). Mcs: 9872/2: Komló-Zobák „Mézes-tető” L2a, K2, K5 (K: 2017). Bd: 0075/3: Turony „Sziget” K2 (K: 2010). 9975/4: Pécs-Nagyárpád „Pécsudvardi-erdő” K1a (K: 1999). Gd: 9877/1: Ófalu „Kalk-tal” K2 (K: 1991). Szd: 9778/1: Szálka „Rác-erdő” J5, K1a, K2 (K: 1992).

Törlendő, helyesbítendő és kétes adatok

Gymnocarpium dryopteris (L.) Newman - Gd: 9778/3: Bátaszék „Kövesdi-erdő” (TóTH I. Zs. in KEVEY 1993: 54). Előző közleményemben (KEVEY 2017a: 361) sajnos elírás történt, téves CEU kód (8778/3) alatt jelent meg. A 9778/3 kód a helyes.

Chaerophyllum aureum L. - R: 8369/3,4?; 8469/1,2?: Csorna (Márton BPM: 1892; MÁRTON in KEVEY 2003: 30). Mcs: 9876/1,2?: Pécsvárad „Zengő” (HoRvát A. O. 1943: 108; HoRvÁt A. O. 1959: 33, 45). Mindkét esetben bizonytalan a lelőhelyek kvadrát szintű azonosítása, de a térképen valamilyen módon jelölendő!

Allium ursinum L. - BSzs: 7800/3: Ez a lelőhely a Vásárosnamény melletti „Bagiszeg-erdő”-re vonatkozna, de törlendő, mert az erdő nem ebben a kvadrátban, hanem a 7899/2 és a 7899/4 kvadrátokban foglal helyet (Lesku Balázzsal és Szigetvári Csabával tisztázva!). Mf: 9077/3: Téves adat (Horváth Andrással tisztázva!).

Scilla vindobonensis Speta - Zs: A Zselicben igen sokat kutattam, de csak két helyen (9872/4: Csertő „Szőlő-hegy”; 9873/1: Almamellék „Sas-rét”) láttam a növényt. Ennek ellenére a flóratérképen elég sok előfordulása van feltüntetve. Kellő rutinnal nem rendelkező térképező a meddő állapotú Galanthus nivalis-sal, vagy a Gagea lutea-val is összetévesztheti. Ezért javasolom az adatok egy részének (9772/1, 9772/2, 9772/3, 9772/4; 9773/1,9773/3) terepi ellenőrzését.

\section{Köszönetnyilvánítás}

Köszönetem illeti azon kollégákat, akik közöletlen adataikat rendelkezésemre bocsátották, s ezzel gazdagították dolgozatom tartalmát: Alexay Zoltán, Barina Zoltán, Bancsó Sándor, Barna Csilla, Bezeczky Árpád, Borhidi Attila, Deme Tamás, Egerszegi Attila, Gál László, Gregorits János, Horvát Adolf Olivér†, Horváth András, Juhász Magdolna, Keszei Balázs, Király Gergely, Kurucz Gábor, Lájer Konrád, Lelkes András, Lendvai Gábor, Lesku Balázs, Molnár Csaba, Nagy Tibor, Novacsek Pétert, Papp László, Pelles Gábor, Pintér András, Rédei Tamás, Stoflitz Ferenc, Toldi Miklós, Tóth István Zsolt, Urbán Sándor, Vajda László†, Vöröss László Zsigmond†, Wágner László. 


\section{Irodalom}

BARINA Z. (2008): Adatok a Dunántúli-középhegység és környéke flórájához. - Flora Pannonica 6: 3-23.

BARThA D., KirÁly G., Schmidt D., TiborCZ V., BARinA Z., CSIKY J., JAKAB G., LESKu B., SChMOtZer A., VidÉKi R., Vojткó A. \& ZóLYomi Sz. (szerk.) (2015): Magyarország edényes növényfajainak elterjedési atlasza. Nyugat-magyarországi Egyetem Kiadó, Sopron.

BÁtori Z., ERdőS L., CSEH V., TölgYesi Cs. \& ARADi E. (2014): Adatok Magyarország flórájához és vegetációjához I. - Kitaibelia 19 (1): 89-104.

BoRHIDI A. (1958a): Adatok Belső-Somogy flórájához. - Botanikai Közlemények 47: 107-108.

BoRHIDi A. (1958b): Belső-Somogy növényföldrajzi tagolódása és homokpusztai vegetációja. - Magyar Tudományos Akadémia Biológiai Csoportjának Közleményei 1: 343-378.

Boros Á. (1935): A Nagykőrös vidéki homoki erdők növényvilága. - Nagykőrösi Múzeumkör Kiadványai 1. Híradó nyomda, Nagykőrös, 22 pp.

Boros Á. (1936): A Duna-Tisza köze kőriserdői és zsombékosai. - Botanikai Közlemények 33: 84-97.

Boros Á. (1970): Florisztikai közlemények V. - Botanikai Közlemények 57 (1): 69-72.

BöLöNI J., MoLNÁR Zs. \& Kun A. (szerk.) (2011): Magyarország élőhelyei. A hazai vegetációtípusok leírása és határozója. ÁNÉR 2011. MTA ÖBKI, pp. 441.

CSIKY J., Baráth K., Bocz V., Deme J., FÜlöP Zs., Kovács D., NAGy K., TAMÁsi B. \& CsikYnÉ Radnai É. (2017): Pótlások Magyarország edényes növényfajainak elterjedési atlaszához V. - Kitaibelia 22 (2): 383-403.

GALAmbos I. (1998): Florisztikai-növényföldrajzi kutatások újabb eredményei a Pannonhalmidombságon. - Kitaibelia 3: 95-96.

HANGAY O. (1889): Erőszakolt flóravidék. - Orvos-Természettudományi Értesítő 11: 153-162.

HaRGitai Z. (1937): Nagykőrös növényvilága. I. A flóra. - Debreceni Református Kollégium Tanárképző Intézete, Debrecen, $54 \mathrm{pp}$.

HoRvát A. O. (1943): Pótlások a „Mecsekhegység és környékének flórájá”-hoz (Additamenta ad floram regionis montium Mecsek). - Botanikai Közlemények 40: 101-112.

HoRvát A. O. (1959): A mecseki bükkösök (Fagetum sylvaticae mecsekense) erdőtípusai. - Janus Pannonius Múzeum Évkönyve 3 [1958]: 31-48.

Horvát A. O. (1976): Pótlások és kiegészítések „A Mecsek-hegység és déli síkjának növényzete” ismeretéhez (1942-1971) III. - Dunántúli Dolgozatok 10: 23-46.

JÁrAI-Komlódi M. (1958): Die Pflanzengesellschaften in dem Turjángebiet von Ócsa-Dabas. - Acta Botanica Academiae Scientiarum Hungaricae 4: 63-92.

JávorKA S. \& Soó R. (1951): A magyar növényvilág kézikönyve I-II. - Akadémiai Kiadó, Budapest, 1120 pp.

KÁRPÁTI I. \& KÁRPÁTI V. (1958): A hazai Duna-ártér erdőtípusai. - Az Erdő 7: 307-318.

KERNER A. (1878): Die Vegetations-Verhältnisse des mittleren und östlichen Ungarns und angrenzenden Siebenbürgens CI. - Österreichische Botanische Zeitschrift 28: 148-155.

Kevey B. (1979): Az Allium ursinum L. magyarországi elterjedése. - Botanikai Közlemények 65 (3) [1978]: 165-175.

KEVEY B. (1981): Adatok Magyarország flórájának és vegetációjának ismeretéhez I. - Botanikai Közlemények 67 (3) [1980]: 179-182.

KEVEY B. (1983): Adatok Magyarország flórájának és vegetációjának ismeretéhez II. - Botanikai Közlemények 70 (1-2): 19-23.

KEVEY B. (1984): Dég parkerdeinek tölgy-kőris-szil ligetei. - Botanikai Közlemények 71 (1-2): 51-61.

KEVEY B. (1985a): Adatok Magyarország flórájának és vegetációjának ismeretéhez III. - Botanikai Közlemények 72 (1-2): 155-158.

KEvEY B. (1985b): Fragmentális szurdokerdők a Villányi-hegységben. Fragmentale Klamm-Wälder im Villány-Gebirge, Süd-Ungarn. - Janus Pannonius Múzeum Évkönyve 29 [1984]: 23-28.

KEVEY B. (1986): A martonvásári „Kastélypark” tölgy-kőris-szil ligeterdői. - Botanikai Közlemények 73 (1-2): 33-42.

KEVEY B. (1987a): A Villányi-hegység bükkösei. The beech-woods of the Villány Mountains, South Hungary. - Janus Pannonius Múzeum Évkönyve 30-31 [1985-1986]: 7-9.

KEVEY B. (1987b): A martonvásári Kastélypark tölgy-kőris-szil ligeterdői. - Botanikai Közlemények 73 (1-2) [1986]: 33-42.

KEVEY B. (1988a): Adatok Magyarország flórájának és vegetációjának ismeretéhez IV. - Botanikai Közlemények 74-75 (1-2) [1987-1988]: 93-100. 
KEVEY B. (1988b): Útmutató a TTSZ őrök részére a Dél-dunántúli OKTH Felügyelőség múködési területén elterjedt veszélyeztetett, védett és fokozottan védett növényeiről. - Országos Környezet- és természetvédelmi Hivatal Dél-Dunántúli Felügyelősége, Pécs, 32 pp.

KEVEY B. (1990): Adatok Magyarország flórájának és vegetációjának ismeretéhez V. - Botanikai Közlemények 76 (1-2) [1989]: 83-96.

KEVEY B. (1993): Adatok Magyarország flórájának és vegetációjának ismeretéhez VI. - Botanikai Közlemények 80 (1): 53-60.

Kevey B. (1998): A szentegáti bükk-állomány társulási viszonyai. - Janus Pannonius Múzeum Évkönyve 41-42 [1996-1997]: 13-26.

KEVEY B. (2001): Adatok Magyarország flórájának és vegetációjának ismeretéhez VIII. - Botanikai Közlemények 88 (1-2): 95-105.

KEVEY B. (2003): A Chaerophyllum aureum L. magyarországi elterjedése. - Kitaibelia 8 (1): 29-34.

KEVEY B. (2005): Adatok magyarország flórájának és vegetációjának ismeretéhez IX. - Botanikai Közlemények 91 (1-2) [2004]: 13-23.

KeveY B. (2007a): A Somogyi-Dráva-ártér gyertyános-tölgyesei (Circaeo-Carpinetum Borhidi 2003 em. KeveY hoc loco). - Somogyi Múzeumok Közleményei 17 (2006): 83-102.

Kevey B. (2007b): A Baranyai Dráva-sík gyertyános-tölgyesei (Circaeo-Carpinetum Borhidi 2003 em. KeVEY 2006b). - Natura Somogyiensis 10: 41-71.

KeveY B. (2007c): A Somogyi-Dráva-ártér tölgy-kőris-szil ligetei (Fraxino pannonicae-Ulmetum Soó in Aszód 1935 corr. Soó 1963). - Somogyi Múzeumok Közleményei 17 [2006]: 103-122.

KEvEY B. (2008): Magyarország erdőtársulásai (Forest associations of Hungary). - Tilia 14: 1-488. + CDadatbázis (230 táblázat + 244 ábra).

KeveY B. (2009): A Zákányi-dombok égerligetei (Carici pendulae-Alnetum glutinosae Borhidi et Kevey 1996). - Kanitzia 16 [2008-2009]: 211-231.

Kevey B. (2010): A Zselic szurdokerdei (Polysticho setiferi-Aceretum pseudoplatani Kevey in Borhidi et Kevey 1996). - Natura Somogyiensis 17: 23-48.

KeveY B. (2012a): A Kelet-Mecsek bükkösei [Helleboro odori-Fagetum (A. O. Horvát 1958) Soó et Borhidi in Soó 1960]. - Acta Naturalia Pannonica 3: 27-48.

Kevey B. (2012b): A Villányi-hegység molyhos tölgyesei (Pubescent oak woods in the Villány Hills). Acta Naturalia Pannonica 4: 35-58.

KeVEy B. (2013a): Belső-Somogy homoki gyertyános-tölgyesei. - (Fraxino pannonicae-Carpinetum Soó et Borhidi in Soó 1962). - Kaposvári Rippl-Rónai Múzeum Közleményei 1: 17-40.

Kevey B. (2013b): Adatok a hazai Dráva menti síkság flórájához. - Kitaibelia 18 (1-2): 105-124.

KEVEY B. (2013c): Korrekció Kevey B. „A Zselic szurdokerdei (Polysticho setiferi-Aceretum pseudoplatani Kevey in Borhidi et Kevey 1996)" c. tanulmányához (Natura Somogyiensis 17 [2010]: 35-60.). Natura Somogyiensis 23: 33-36.

KEVEY B. (2013d): A Zákányi-dombok gyertyános-tölgyesei (Anemoni trifoliae-Carpinetum Borhidi et Kevey 1996). - Kaposvári Rippl-Rónai Múzeum Közleményei 1: 41-64.

KeVEY B. (2013e): Korrekció KeVEY B. A Zákányi-dombok égerligetei (Carici pendulae-Alnetum glutinosae Borhidi et Kevey 1996) című tanulmányhoz [Kanitzia - Botanikai folyóirat (2008-2009) 16: 211-231]. - Kanitzia 20: 241-242.

KeveY B. (2014): A Bakonyalja homokvidékének erdei V. Gyertyános-tölgyesek (Convallario-Carpinetum Kevey 2008). - Folia Musei Historico-Naturalis Bakonyiensis 31: 47-72.

KEVEY B. (2015a): Adatok Magyarország flórájának és vegetációjának ismeretéhez X. - Botanikai Közlemények 102 (1-2): 39-60.

Kevey B. (2015b): A Bakonyalja homokvidékének erdei VI. Égerligetek (Aegopodio-Alnetum glutinosae Kárpáti V., Kárpáti I. et Jurko ex Šomšák 1961). - Folia Musei Historico-Naturalis Bakonyiensis 32: 49-70.

KEveY B. (2015c): A Tengelici-homokvidék zárt homoki tölgyesei (Polygonato latifolii-Quercetum roboris Borhidi in Borhidi et Kevey 1996). - Natura Somogyiensis 27: 5-36.

KEVEY B. (2015d): A Nyugat-Mecsek gyertyános-tölgyesei - Oak-hornbeam forests in the western Mecsek Mountains [Asperulo taurinae-Carpinetum (A. O. Horvát 1958) Soó \& Borhidi in Soó 1962]. Acta Naturalia Pannonica 8: 5-41.

KEveY B. (2015e): A vasi Rába-völgy gyertyános-tölgyesei (Veronico montanae-Carpinetum scilletosum drunensis Kevey subass. nova). - Kanitzia 22: 211-237.

KEvEY B. (2016): A Villányi-hegység gyertyános-tölgyesei [Asperulo taurinae-Carpinetum (A. O. Horvát 1946) Soó et Borhidi in Soó 1962]. - Acta Naturalia Pannonica 10: 21-46. 
KEvEY B. (2017a): Pótlások Magyarország edényes növényfajainak elterjedési atlaszához IV. - Kitaibelia 22 (2): 358-382.

KeveY B. (2017b): A Mohácsi-sziget fehérnyár-ligetei (Senecioni sarracenici-Populetum albae Kevey in Kevey et Borhidi 1996). - Botanikai Közlemények 104 (1): 131-146.

Kevey B. \& AleXAY Z. (1992): Adatok a Szigetköz flórájához. - Acta Ovariensis 34 (1): 29-37.

KEVEY B. \& AlEXAY Z. (1996): A Szigetköz tőzegpáfrányos-égerlápjai (Thelypteridi-Alnetum). - Széchenyi István Főiskola, Tudományos Közlemények 7: 1-24.

Kevey B. \& BARANYI Á. (2002): A Nyugati-Mecsek égerligetei (Carici pendulae-Alnetum Borhidi \& Kevey 1996). - Janus Pannonius Múzeum Évkönyve 40-45 [1999-2000]: 5-24.

Kevey B. \& Barna Cs. (2016): A hazai Felső-Tisza-vidék füzligetei (Leucojo aestivi-Salicetum albae Kevey in Borhidi et Kevey 1996). - Kitaibelia 21 (1): 78-100.

Kevey B. \& BARTHA D. (2010): Szúrós csodabogyó - Ruscus aculeatus L. - Tilia 15: 271-301.

KEVEY B., BoRHIDI A. \& KLUJBER K. (1998): Belső-Somogy homoki bükkösei (Leucojo verno-Fagetum Kevey et Borhidi 1992). - Somogyi Múzeumok Közleményei 13: 241-256.

Kevey B., Ferencz L. \& Tóth I. (2006): A magyarországi Alsó-Duna-ártér fekete galagonya cserjései (Leucojo aestivi-Crataegetum nigrae Kevey, Ferencz et Tóth ass. nova). - Kanitzia 14: 207-239.

Kevey B., Ferencz L. \& Tóth I. (2010): Korrekció: Kevey B. - Ferencz L. - Tóth I. A magyarországi AlsóDuna-ártér fekete galagonya cserjései (Leucojo aestivi-Crataegetum nigrae Kevey, Ferencz et Tóth ass. nova) c. tanulmányhoz [Kanitzia 14: 207-239]. - Kanitzia 17 (2010): 223.

Kevey B. \& Horvát A. O. (2000): Pótlások és kiegészítések „A Mecsek-hegység és déli síkjának növényzete" ismeretéhez (1972-2000). - Folia Comloensis 9: 5-70.

Kevey B. \& HuszÁr Zs. (1999): A Háros-sziget fehérnyár-ligetei (Senecioni sarracenici-Populetum albae Kevey in Kevey \& Borhidi 1996). - Természetvédelmi Közlemények 8: 37-48.

Kevey B., JuhÁsZ M., KlujBer K. \& Borhidi A. (1992b): A Boronkamelléki Tájvédelmi Körzet védett növényei. - Dunántúli Dolgozatok (A) Természettudományi Sorozat 7: 27-58.

KeveY B. \& Kovács J. A. (2010): A Mura-vidék gyertyános-tölgyesei (Veronico montanae-Carpinetum Kevey 2008). - Kanitzia 17: 195-221.

Kevey B. \& KovÁcs J. A. (2011): A Mura-vidék tölgy-kőris-szil ligetei (Carici brizoidis-Ulmetum Kevey 2008). - Kanitzia 18: 195-240.

Kevey B. \& LendvaI G. (2015): A Tengelici-homokvidék gyertyános-tölgyesei (Convallario-Carpinetum Kevey 2008). - Natura Somogyiensis 26: 5-38.

Kevey B., Lendvai G. \& Simon Gy. (2014): A Velencei-hegység gyertyános-tölgyesei (Corydali cavaeCarpinetum Kevey 2008). - Kanitzia 21: 219-244.

Kevey B., MajLÁth I. \& MolnáR M. (2016): Changes in the hardwood groves of the Martonvásár manor park (Hungary) in the last 30 years. - Acta Botanica Hungarica 58 (3-4): 265-286. + Table S1-S3.

Kevey B., Orosz-Kovács Zs., Tóth I. \& BorhiDi A. (1992a): Adatok a Béda-Karapancsa Tájvédelmi Körzet flórájához. - Dunántúli Dolgozatok (A) Természettudományi Sorozat 6: 13-25.

Kevey B., PapP L. \& LENDVAi G. (2017a): A Nyírség gyertyános-tölgyesei (Convallario-Carpinetum Kevey 2008). - Botanikai Közlemények 104 (1): 147-164. + Elektronikus mellékletek (E1-E3 táblázat).

Kevey B., PAPP L. \& LendVAi G. (2017b): A Nyírség tölgy-kőris-szil ligetei (Fraxino pannonicae-Ulmetum Soó in Aszód 1935 corr. Soó 1933). - Kitaibelia 22 (1): 179-220.

Kevey B. \& Toldi M. (2013): A Zákányi-dombok égeres mocsárerdei (Angelico sylvestri-Alnetum glutinosae Borhidi in Borhidi \& Kevey 1996). - Natura Somogyiensis 23: 37-74.

KEvEY B. \& TóTH I. (2000): Adatok a hazai Alsó-Duna-ártér flórájához. - Kitaibelia 5 (1): 131-143.

KEvEY B. \& TótH I. Zs. (2016): Égerlápok a Tengelici homokvidéken (Carici elongatae-Alnetum glutinosae W. Koch 1926). - Kaposvári Rippl-Rónai Múzeum Közleményei 4: 13-30.

KeveY B. \& TóTH V. (2006): A Baranyai-Dráva-sík fehér nyárligetei (Senecioni sarracenici-Populetum albae Kevey in Borhidi \& Kevey 1996). - Natura Somogyiensis 9: 47-62.

KIRÁLY G. (szerk.) (2009): Új magyar füvészkönyv. Magyarország hajtásos növényei. Határozókulcsok. Aggteleki Nemzeti Park Igazgatóság, Jósvafó, 616 pp.

LENDVAI G., HoRvÁth A. \& KeVEY B. (2014): Tatárjuharos tölgyesek (Aceri tatarici-Quercetum pubescentisroboris Zólyomi 1957) a Mezőföldön. - Botanikai Közlemények 101 (1-2): 145-187.

Molnár Cs., Haszonits Gy., Malatinszky Á., Kovács G. K., Kovács G., NaGY T., MolnÁr V. A. \& TAKÁcs A. (2017): Pótlások Magyarország edényes növényfajainak elterjedési atlaszához III. - Kitaibelia 22 (1): 122-146.

Molnár Cs., Lengyel A., Molnár V. A., NAGY T., Csábi M. \& TAKÁcs A. (2016): Pótlások Magyarország edényes növényfajainak elterjedési atlaszához II. - Kitaibelia 21 (2): 227-252. 
KEVEY (2018): Pótlások Magyarország edényes növényfajainak elterjedési atlaszához VII.

NiKLFELD H. (1971): Bericht über die Kartierung der Flora Mitteleuropas. - Taxon 20 (4): 545-571.

RÉDL R. (1942): A Bakonyhegység és környékének flórája. - In: Soó R. (szerk.), Magyar Flóramúvek V. Editio Ordinis Scholarum Piarum, Veszperém, 159 pp. + 1 chart.

ROZNER Gy. (2011): Védett növényfajok előfordulási adatai Észak-Somogyban. - Natura Somogyiensis 19: 5-16.

Simon T. (1992): A magyarországi edényes flóra határozója. Harasztok - Virágos növények. Tankönyvkiadó, Budapest, 892 pp.

Takács A., Nagy T., SRamkó G., Lovas-Kiss Á., Süveges K., LukÁcs B. A., Fekete R., LöKi V., Malatinszky Á., E. Vojtkó A., Koscsó J., Pfliegler W. P., Nótári K. \& Molnár V. A. (2016): Pótlások a Magyarország edényes növényfajainak elterjedési atlaszához I. - Kitaibelia 21 (1): 101-115.

Vојтко́ A. (2001): A Bükk hegység flórája. - Sorbus Kiadó, Eger, 340 pp.

Zólyomi B. (1969): Természetes növényzet. - In: PÉCSI M. (szerk.), A tiszai Alföld. Akadémiai Kiadó, Budapest, 212-215.

\section{Rövidítések}

ÁNÉR élőhelyek kódjai

D2: kékperjés rétek

J1a: füzlápok

J2: Láp- és mocsárerdők

J3: bokorfüzesek

J4: Fűz-nyár ligeterdők

J5: égerligetek

J6: keményfás ártéri erdők

K1a: gyertyános-kocsányos

tölgyesek

\section{Földrajzi tájak rövidítései}

A - Alpokalja
B - Bakony
Ba - Bakonyalja
Bd - Baranyai-dombság
Bds - Balfi-dombság
BDs - Baranyai Dráva-sík
Bf - Balaton-felvidék
Bk - Bodrogköz
BS - Belső-Somogy
BSzs - Bereg-Szatmári-sík
Bö - Börzsöny
Bü - Bükk
Cssz - Csepel-sziget
DB - Déli-Bakony
Dk - Drávaköz
DTk - Duna-Tisza köze
DZ - Dél-Zala
ÉZ - Észak-Zala
G - Gerecse
Gd - Geresdi-dombság
Ghv - Gönyüi-homok-vidék

LY1: szurdokerdők

LY2: törmeléklejtő-erdők

LY4: tölgyes jellegű sziklaerdők és tetőerdők

M8: száraz-félszáraz erdő- és cserjés-szegélyek

OF: magaskórós ruderális

gyomnövényzet

S1: akácültetvények

L2b: cseres-kocsányos tölgyesek

L5: alföldi zárt kocsányos tölgyesek

H - Hanság
HNs - Harkány-Nagynyárádi-sík
Is - Ikva-sík
J - Jászság
K - Karancs
Kh - Kőszegi-hegység
Khg - Keszthelyi-hegység
KS - Külső-Somogy
KTv - Középső-Tisza-vidék
Köv - Körös-vidék
Kv - Kerka-vidék
Má - Mura-ártér
Mcs - Mecsek
Mf - Mezőföld
Mh - Marcali-hát
Mm - Marcal-medence
Msz - Mohácsi-sziget
Mv - Mura-vidék
Ny - Nyírség
P- Pilis
R - Rábaköz

Sd - Sokorói-dombság

SDs - Somogyi Dráva-sík

Sh - Soproni-hegység

Sk - Sárköz

Sz - Szigetköz

Szd - Szekszárdi-dombság

Szsz - Szentendrei-sziget

Tm - Tapolcai-medence

Th - Tolnai-hegyhát

Tk - Tornai-karszt

Tv - Turján-vidék

V - Völgység

Vehg - Velencei-hegység

Vlhg - Villányi-hegység

Vh - Vasi-hegyhát

Vr - Vértes

VRv - Vasi Rába-völgy

Zd - Zákányi-dombok

Zh - Zempléni-hegység

Zm - Zámolyi-medence

Zs - Zselic

Egyéb rövidítések

! (lelőhelyek után): a szerző által említett helyen a növényt magam is láttam BPM: Természettudományi Múzeum Herbáriuma, Budapest ex litt.: ex litteris (írásbeli közlés) ex verb.: ex verbis (szóbeli közlés) ined.: ineditum (kiadatlan közlés) K: KEVEY ined. 